Open Access

Nora Lustig ${ }^{\mathrm{a}, \star}$

\title{
Inequality and Fiscal Redistribution in Middle Income Countries: Brazil, Chile, Colombia, Indonesia, Mexico, Peru and South Africa
}

DOI 10.1515/jgd-2016-0015

\begin{abstract}
This paper examines the redistributive impact of fiscal policy for Brazil, Chile, Colombia, Indonesia, Mexico, Peru and South Africa using comparable fiscal incidence analysis with data from around 2010. The largest redistributive effect is in South Africa and the smallest in Indonesia. Success in fiscal redistribution is driven primarily by redistributive effort (share of social spending to GDP in each country) and the extent to which transfers/subsidies are targeted to the poor and direct taxes targeted to the rich. While fiscal policy always reduces inequality, this is not the case with poverty. When pensions are not considered a transfer, fiscal policy increases poverty in Brazil (over and above market income poverty) due to high consumption taxes on basic goods. Total spending on education is pro-poor except for Indonesia, where it is neutral in absolute terms. Health spending is pro-poor in Brazil, Chile and South Africa, roughly neutral in absolute terms in Mexico, and not pro-poor in Indonesia and Peru.
\end{abstract}

Keywords: developing countries; fiscal incidence; inequality; poverty; social spending.

JEL Codes: H22; H5; D31; I3.

\section{Introduction}

On average, advanced countries are less unequal than other regions of the world. Around 2010, the average Gini coefficient for advanced economies was roughly

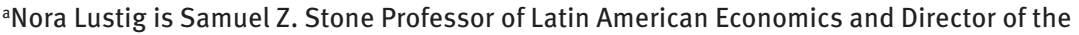
Commitment to Equity Institute (CEQI), Tulane University and nonresident fellow of the Center for Global Development and the Inter-American Dialogue.

*Corresponding author: Nora Lustig, Department of Economics, Tulane University, New Orleans, LA, USA, e-mail: nlustig@tulane.edu
} 
equal to 0.30 while the Gini coefficient for the rest of the world was approximately equal to $0.40 .{ }^{1}$ Advanced countries, however, are not "born" less unequal. Relatively low inequality is the result of fiscal redistribution on a large scale. In the European Union, for example, the reduction in the Gini coefficient induced by direct taxes and transfers hovers around 21 percentage points if social insurance pensions are considered a transfer and 9 percentage points if pensions are assumed to be deferred income (EUROMOD 2015). ${ }^{2}$ Higgins et al. (2015) find that in the United States, the figures are 11 and 7 percentage points, respectively. ${ }^{3}$

How much fiscal redistribution takes place in middle-income countries? In this paper, I examine the redistributive impact of fiscal policy in Brazil, Chile, Colombia, Indonesia, Mexico, Peru and South Africa, seven middle-income countries that were available in the commitment to equity (CEQ) project. ${ }^{4}$ In particular, I address the following questions: What is the impact of fiscal policy on inequality and poverty? What is the contribution of direct taxes and transfers, net indirect taxes and spending on education and health to the overall reduction in inequality? How pro-poor is spending on education and health? To put the fiscal redistribution efforts in context, I start by presenting a brief overview of the evolution of inequality (measured by the Gini coefficient) by region and income per capita categories.

The information used here is based on the following fiscal incidence analyses: Brazil (Higgins and Pereira 2014), Chile (Martinez-Aguilar et al. 2016), Colombia (Lustig and Melendez 2015), Indonesia (Afkar et al. 2016), Mexico (Scott 2014), Peru (Jaramillo 2014) and South Africa (Inchauste et al. 2015). Lustig et al. (2014) and Lustig $(2015 a, b)^{5}$ provide syntheses of the results. These studies use a

1 The Gini coefficients are simple averages calculated with the following data. Advanced countries: OECD Income Distribution Database: Gini, poverty, income, Methods and Concepts. OECD. Accessed December, 22, 2014. http://www.oecd.org/social/income-distribution-database.htm. Developing countries except for Latin America and the Caribbean: PovcalNet: an online poverty analysis tool. The World Bank. Accessed November 05, 2014. http://iresearch.worldbank.org/ PovcalNet/index.htm?0,0. Latin America and the Caribbean: Socio-Economic Database for Latin America and the Caribbean (CEDLAS and The World Bank). Accessed July 22, 2013. http://sedlac. econo.unlp.edu.ar/eng/statistics-detalle.php?idE=35.

2 If pensions are assumed to be deferred income, they are counted as part of market or consumable income of people receiving them. The data are for 2010.

3 Data is for 2011.

4 Launched in 2008, the CEQ project is an initiative of the Center for Inter-American Policy and Research (CIPR) and the Department of Economics, Tulane University, the Center for Global Development and the Inter-American Dialogue. For more details visit www.commitmentoequity.org. 5 The analysis is based on the country studies that have been undertaken and completed under the CEQ project by January 2015. The authors of the country studies are: Brazil (Higgins and Pereira 2014), Chile (Martinez-Aguilar et al. 2016), Colombia (Lustig and Melendez 2015), Indonesia (Afkar et al. 2016), Mexico (Scott 2014), Peru (Jaramillo 2014) and South Africa (Inchauste et al. 2015). 
common fiscal incidence method described in detail in Lustig and Higgins (2013) and of which a brief summary is included below. Known in the literature as the “accounting approach” because it ignores behavioral responses and general equilibrium effects, incidence analysis of public spending and taxation is designed to respond to the question of who benefits from government transfers and who ultimately bears the burden of taxes in the economy. With a long tradition in applied public finance, tax and benefit incidence analysis is an efficient instrument to evaluate whether fiscal policy has the desired effect on poverty and inequality (Musgrave 1959; Pechman 1985; Martínez-Vazquez 2008). The increasing availability of household surveys containing sufficient information to assess the effects of fiscal policy on incomes and their distribution, has increased considerably the number of empirical studies in this area.

The contribution of specific fiscal interventions is calculated using the marginal contribution method. This method is equivalent to asking the question: how much would have inequality changed if the fiscal intervention of interest had not been there (keeping the rest of the fiscal system in place) ${ }^{6}$ The progressivity and pro-poorness of education and health spending are determined based on the size and sign of the relevant concentration coefficient. In keeping with generally accepted convention, spending is regressive when the concentration coefficient is higher than the market-income Gini. Spending is progressive, when the concentration coefficient is lower than the market-income Gini. Spending is pro-poor when the concentration coefficient is not only lower than the marketincome Gini, but also has a negative value. ${ }^{7}$ A negative concentration coefficient implies that per capita spending tends to be higher the poorer the individual. ${ }^{8}$ When the concentration coefficient equals zero, per capita spending is the same across the distribution: spending is neutral in absolute terms. By definition, government spending that is pro-poor (or neutral in absolute terms) is also progressive. However, not all government spending that is progressive is pro-poor.

This article makes three important contributions. First, because the fiscal incidence analysis is comprehensive, one can estimate both the overall impact of the "fiscal system" as well as the marginal contribution of the main fiscal interventions to the overall reduction in inequality. The main fiscal interventions included here are: direct taxes, direct transfers, net indirect taxes and transfers in-kind (in the form of education and healthcare services). Second, the analysis

6 This method is described and used in OECD (2011). The analytical merits of this method compared to the sequential method are discussed in Lustig et al. (forthcoming).

7 Implicit in the rankings is the assumption that concentration curves do not cross.

8 This does not need to happen at every income level. A concentration coefficient will be negative as long as the concentration curve lies above the diagonal. 
includes the effects of fiscal policy not only on inequality but also on poverty. Third, because the seven studies apply a common methodology, results are comparable across countries.

The findings can be summarized as follows. Overall, there is evidence that in the 2000s the average inequality for the world (measured by the average of the unweighted Gini coefficients) declined very slightly. There also appears evidence of convergence: countries with initially higher (lower) levels of inequality more frequently experienced a decline (increase). There are two regions which show noticeable declines in average inequality: Latin America and the Caribbean and South Asia.

The impact of fiscal policy on income redistribution results in various degrees of equalization with the largest redistributive effect in South Africa and the smallest one in Indonesia. South Africa's result can be attributed to the combination of a large redistributive effort with transfers targeted to the poor and direct taxes targeted to the rich. In spite of this, South Africa remains the most unequal of the seven countries. Income redistribution tends to be higher in more unequal countries to start with: redistribution is considerable higher in countries with higher market income inequality such as South Africa and Brazil than in countries with relatively lower inequality such as Indonesia and Peru. As expected, the level of income redistribution and the size of the budget allocated to social spending (as a share of GDP) are associated. However, differences across countries suggest that institutional, political and demographic factors also affect the level of redistribution. Redistribution is considerably larger in countries with high social spending, such as Brazil and South Africa, than in Indonesia and Peru, where social spending is more limited.

Direct taxes and direct transfers generally exercise an equalizing force. Indirect taxes are unequalizing in Colombia and Indonesia, but equalizing in Chile and neutral in South Africa. Contributory pensions are equalizing in Brazil, Chile and Indonesia, and slightly unequalizing in Colombia, Mexico and Peru. Per capita total spending on public education tends to be higher for poorer households (i.e. pro-poor) in all countries except for Indonesia, where the per capita benefit is roughly the same for all households. Government spending on tertiary education increases with income in all countries, but only in Indonesia it increases inequality. Health spending is pro-poor (that is, per capita spending declines with income) in Brazil, Chile, and South Africa. In Mexico, the per capita benefit is roughly the same across the income scale. In Indonesia and Peru, health spending per person tends to increase with income but still reduces inequality.

Although education and health spending have the highest redistributive effect of the different components of fiscal policy, the existing information cannot disentangle to what extent the progressivity or pro-poorness of education and health spending is a result of differences in household or personal characteristics 
that could explain a more intense use by poorer households (e.g. having more children and worse health) or the "opting-out" of those better-off.

While fiscal policies overall unambiguously reduce income inequality, in terms of poverty reduction, the outcome is less auspicious. In Chile, Indonesia, Mexico, Peru, Colombia and South Africa poverty after cash transfers, net direct taxes and net indirect taxes is lower than market income poverty. In Brazil, however, income poverty would be higher if public pensions are considered as deferred income rather than a direct transfer, which means that a portion of the poor who are not pensioners are net payers into the fiscal system and are, thus, impoverished by the fiscal system (Higgins and Lustig 2016).

The paper is organized as follows. Section 2 presents a brief overview of levels and trends in inequality for the world, by region and income level, and by country. Section 3 presents spending allocation and revenue raising patterns for the seven countries. Section 4 includes a brief description of the fiscal incidence methodology. Sections 5 and 6 discuss the impact of fiscal policy on inequality and poverty, respectively. Section 7 examines the pro-poorness of government spending on education and health. Section 8 concludes.

\section{The Evolution of Inequality in the Developing World}

Table 1 presents the (unweighted) average Gini coefficient by region and income category for the period 2000-2010. ${ }^{9}$ There are several observations to be made. In 2010, world inequality can be classified as moderate: the average Gini is just below 0.4 , the median of the difference between the region with the lowest and the highest Gini coefficient. The level of inequality in Advanced Economies, Eastern Europe and Central Asia and South Asia is below the world average; it is above the world average in Sub-Saharan Africa and Latin America and the Caribbean. East Asia's inequality is roughly the same as the world's average. Latin America and the Caribbean is the region with the highest extent of inequality by far: its average Gini is 12 points above the world's average. Using the World Bank's clas-

9 The welfare measure utilized here is per capita disposable income (i.e., income after direct taxes and transfers) for Latin America and the Caribbean (SEDLAC), equivalized disposable income for OECD non-LAC countries (IDD), and per capita consumption for the rest (World Bank's POVCAL). A caveat is in order. The microdata for advanced countries distinguishes between income before and income after taxes and transfers in a clear way, this is not the case, however, for the income-based surveys in Latin America. 
Table 1: Average inequality by region and income level (5 year averages) 2000-2010.

\begin{tabular}{|c|c|c|c|}
\hline \multirow[t]{2}{*}{ Region $^{b}$} & \multicolumn{3}{|c|}{ Gini coefficient ${ }^{a}$} \\
\hline & 2000 & 2005 & 2010 \\
\hline World & 0.39 & 0.385 & 0.38 \\
\hline Advanced economies & 0.298 & 0.302 & 0.304 \\
\hline East Asia and the Pacific & 0.38 & 0.391 & 0.389 \\
\hline Eastern Europe and Central Asia & 0.331 & 0.329 & 0.333 \\
\hline Latin America and the Caribbean & 0.551 & 0.532 & 0.502 \\
\hline Middle East and North Africa & & & Not enough data \\
\hline South Asia & 0.354 & 0.351 & 0.328 \\
\hline Sub-Saharan Africa & 0.445 & 0.434 & 0.44 \\
\hline \multicolumn{4}{|l|}{ Income Categoryc } \\
\hline Low income countries & 0.316 & 0.32 & 0.323 \\
\hline Lower middle income countries & 0.421 & 0.412 & 0.399 \\
\hline Upper middle income countries & 0.442 & 0.436 & 0.428 \\
\hline Total middle income countries & 0.431 & 0.423 & 0.413 \\
\hline High income countries & 0.397 & 0.386 & 0.386 \\
\hline
\end{tabular}

Source: Author's calculations based on:

OECD Income Distribution Database: Gini, poverty, income, Methods and Concepts. OECD.

Accessed December, 22, 2014. http://www.oecd.org/social/income-distribution-database.htm.

PovcalNet: an online poverty analysis tool. The World Bank. Accessed November 05, 2014. http://iresearch.worldbank.org/PovcalNet/index.htm?0,0.

Socio-Economic Database for Latin America and the Caribbean (CEDLAS and The World Bank). Accessed July 22, 2013. http://sedlac.econo.unlp.edu.ar/eng/statistics-detalle.php?idE=35.

${ }^{a}$ Data for Latin America comes from SEDLAC (household per capita income Gini series). Gini Estimates for OECD countries outside of Latin America are based on OECD IDD (Gini at disposable income, post taxes and transfers, using square root of family size equivalence scales). All other Gini estimates are based on POVCAL (household per capita consumption Gini). Regional Gini Coefficients are calculated in two steps. First, for each country we take the average estimated Gini Coefficient for the 5-year period surrounding the displayed year. For example, we use 1998, 1999, 2000, 2001, and 2002 for 2000 . Second, for all countries for whom we have estimates in each of the 3 years above, we take a simple, unweighted average across the region. Where there were fewer than three countries that we could track across all three periods, we do not report the regional average.

${ }^{b}$ Regional Averages were based on the following countries with the welfare measure (with I denoting income or $($ denoting consumption) in parentheses:

- Advanced Economies: Australia (I), Canada (I), Czech Republic (I), Denmark (I), Finland (I), France (I), Germany (I), Greece (I), Israel (I), Italy (I), Japan (I), Luxembourg (I), Netherlands (I), New Zealand (I), Norway (I), Sweden (I), United Kingdom (I), and United States (I)

- East Asia and the Pacific: China (C), Indonesia (C), Laos (C), Philippines (C), Thailand (C), and Vietnam (C).

- Eastern Europe and Central Asia: Albania (C), Armenia (C), Azerbaijan (C), Belarus (C), Croatia (C), Georgia (C), Kazakhstan (C), Kyrgyz Republic (C), Latvia (C), Lithuania (C), Macedonia (C), Moldova (C), Romania (C), Russian Federation (C), Serbia (C), Tajikistan (C), Turkey (C), and Ukraine (C). 
Table 1 (continued)

- Latin America and the Caribbean: Bolivia (I), Brazil (I), Chile (I), Colombia (I), Costa Rica (I), Dominican Republic (I), Ecuador (I), Guatemala (I), Honduras (I), Mexico (I), Nicaragua (I), Panama (I), Paraguay (I), and Peru (I).

- South Asia: Bangladesh (C), Pakistan (C), and Sri Lanka (C).

- Sub-Saharan Africa: Burkina Faso (C), Ethiopia (C), Madagascar (C), Malawi (C), Mali (C), Mauritania (C), Rwanda (C), Senegal (C), South Africa (C), Tanzania (C), Uganda (C), and Zambia (C).

- The classification by income category follows the World Bank (February 2015): http://data.worldbank.org/about/country-and-lending-groups.

sification of countries by income level, low income countries' inequality is well below the world's average. The most unequal group is comprised of upper middle income countries, a reflection of the influence of unequal Latin America since a significant number of middle income countries are from that region.

Inequality trends feature what has already been documented: there is evidence in support of a slight decline in world inequality ${ }^{10}$ and inequality convergence. ${ }^{11}$ In particular, Latin America and the Caribbean - which was and still is the most unequal region - has experienced a significant decline. ${ }^{12}$ Inequality in lowincome countries has experienced a slight increase, while inequality in middle and high income countries has fallen a bit. Convergence is graphically apparent on Figure 1 below. This figure also shows that declining inequality has been more frequent in the 2000s. Of the 78 countries included in the graph, 45 experienced a decline, 30 experienced an increase, and three experienced no change.

In Figure 2, one can observe the level and evolution of the Gini coefficient for the seven countries analysed here. South Africa features the highest levels of inequality, followed by Brazil and Chile.Indonesia has the lowest level of inequality in this group, and Mexico and Peru are closer to the most unequal. One important aspect to bear in mind, however, is that the data for Indonesia and South Africa is consumption-based while it is income-based for the rest. A well-known fact is that consumption-based inequality data tends to be lower than income-based one. Hence, Indonesia and South Africa are likely to be more unequal in the income per capita space than shown below. ${ }^{13}$ Regarding trends,

10 World inequality here means the average of unweighted Ginis. Note that it is different from the concept of global inequality which integrates all the individuals in the world (from all the available household surveys) under a single ranking.

11 See, for example, Bourguignon (2015) and Ravallion (2003).

12 The decline in inequality in Latin America has been analyzed by López-Calva and Lustig (2010) and Cornia (2014), among others.

13 For South Africa this is evident when one looks at the income-based measures in Inchauste et al. (2015). 


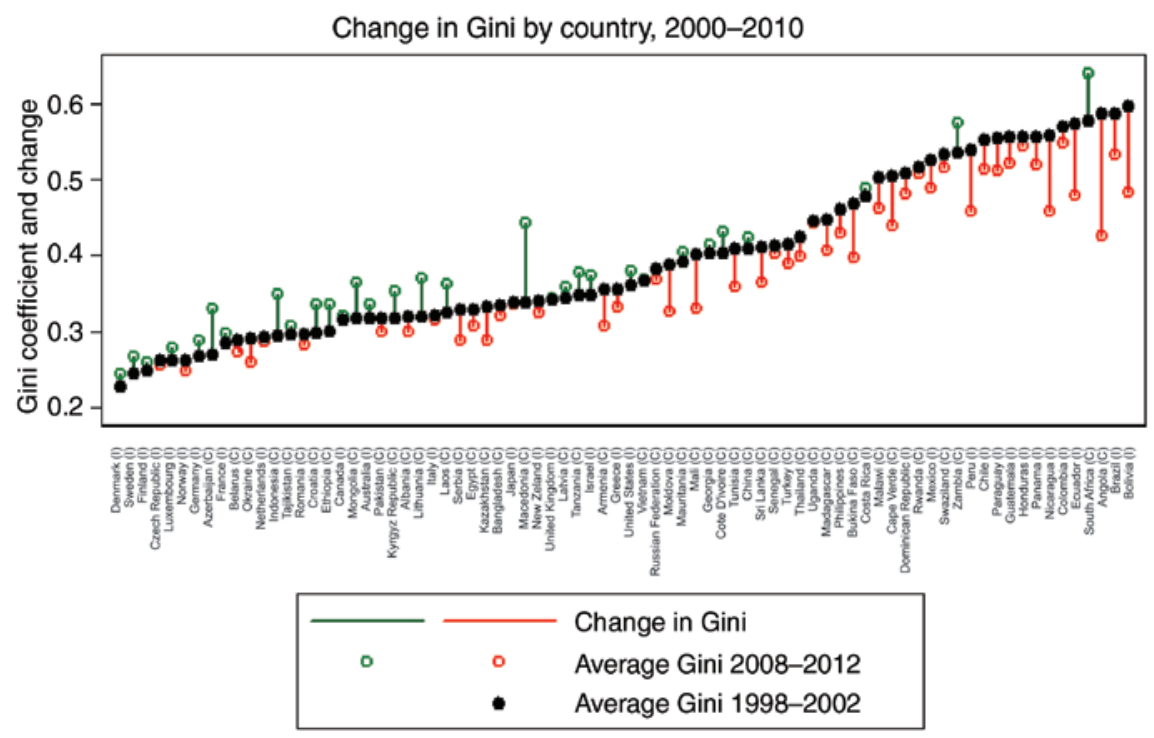

Figure 1: Gini coefficient: level and change by country: 2000-2010.

Source: Author's calculations based on:

- OECD Income Distribution Database: Gini, poverty, income, Methods and Concepts. OECD. Accessed December, 22, 2014. http://www.oecd.org/social/income-distribution-database.htm.

- PovcalNet: an online poverty analysis tool. The World Bank. Accessed November 05, 2014. http://iresearch.worldbank.org/PovcalNet/index.htm?0,0.

- Socio-Economic Database for Latin America and the Caribbean (CEDLAS and The World Bank). Accessed July 22, 2013. http://sedlac.econo.unlp.edu.ar/eng/statistics-detalle.php?idE=35. Notes:

- All Gini estimates from Latin America use SEDLAC as their source. Gini Estimates for OECD countries outside of Latin America are based on OECD IDD. All other Gini estimates are based on POVCAL.

- Change in Gini is calculated as the average Gini coefficient between 2008 and 2012 minus the average Gini coefficient between 1998 and 2002.

- (I) denotes Gini based on per capita income and (C) denotes Gini based on per capita consumption.

Figure 2: The evolution of inequality in Brazil, Chile, Colombia, Indonesia, Mexico, Peru and South Africa.

Source: Author's calculations based on:

- PovcalNet:an online poverty analysis tool. The World Bank. Accessed November 05, 2014. http://iresearch.worldbank.org/PovcalNet/index.htm?0,0.

- Socio-Economic Database for Latin America and the Caribbean (CEDLAS and The World Bank). Accessed July 22, 2013. http://sedlac.econo.unlp.edu.ar/eng/statistics-detalle.php?idE=35. Notes:All Gini estimates from Latin America use SEDLAC as their source and Indonesia and South Africa are based on POVCAL Gini Coefficients. 

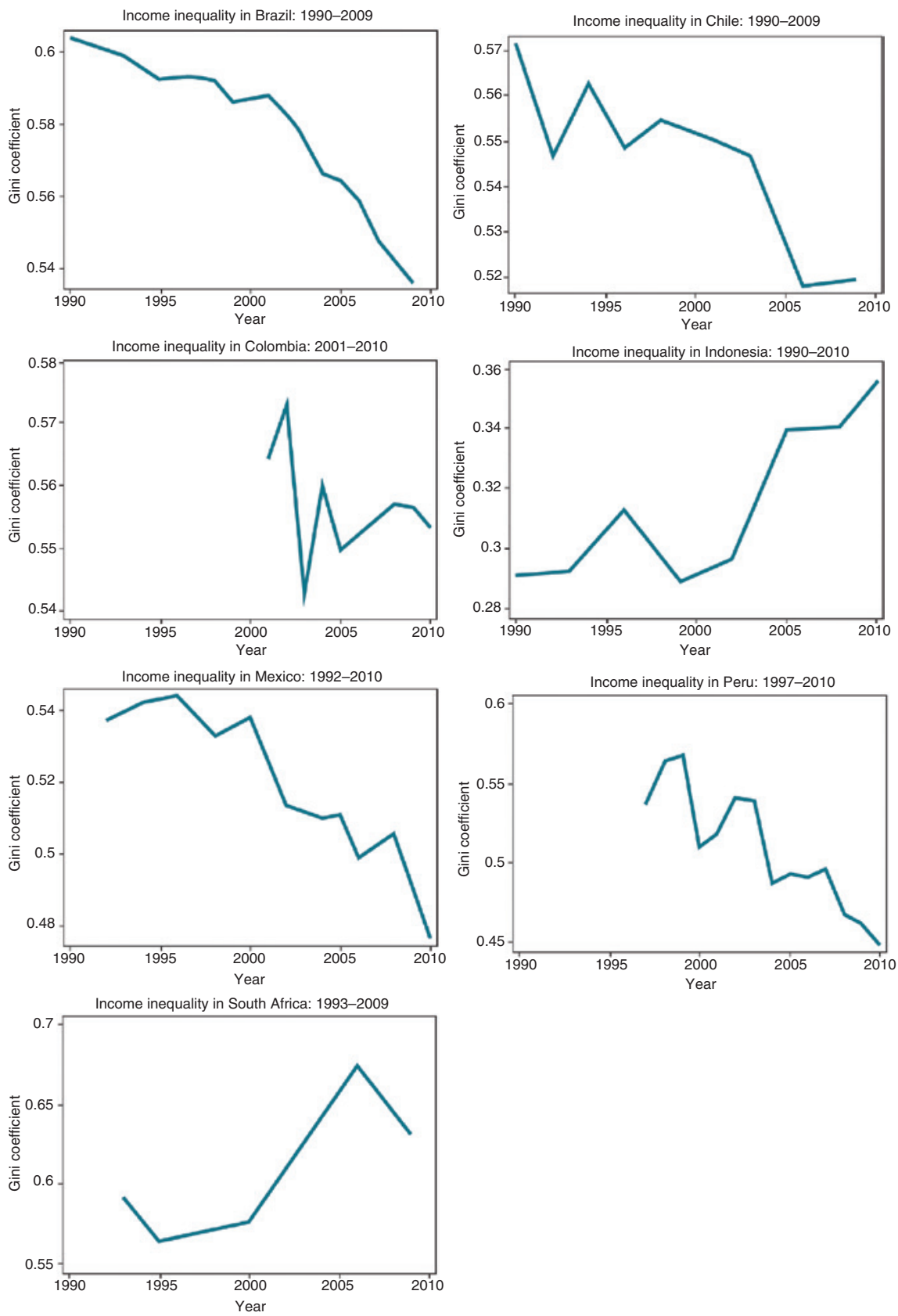
the four countries from Latin America show a decline while Indonesia and South Africa experienced an increase. ${ }^{14}$ The data for Colombia, however, has to be taken with caution because of changes in the household surveys used as source for these trends.

\section{Budget Size, Social Spending and Taxation}

The redistributive potential of a country is determined first and foremost by the size and composition of its budget and how government spending is financed. Figure 3 shows social spending as a share of GDP for around 2010. Social spending includes direct transfers, contributory and noncontributory pensions, and public spending on education and health. ${ }^{15}$ It does not include housing subsidies or other forms of social spending. As one can observe, the seven countries are quite heterogeneous in terms of government size and resources committed to social spending. Brazil and South Africa stand out as countries with a relatively large government and more fiscal resources devoted to social spending. Brazil, for instance, allocates 23.7 percent of its GDP to direct transfers, pensions, education and health. On the other extreme is Indonesia, where the share is 5.4 percent.

Panel A in Figure 3 shows the composition of social spending for the following categories: direct transfers, pensions, education and health around 2010. Direct transfers include noncontributory (social) pensions. Brazil and South Africa devote a sizeable share to direct transfers: 4.2 percent and 3.8 percent, respectively. In addition to Bolsa Familia and the basic noncontributory

14 For an analysis of the factors behind the increase in inequality in post-apartheid South Africa, see Leibbrandt et al. (2010).

15 Note that the numbers included in this section are those provided by the authors of the individual studies based on government statistics. The numbers do not necessarily match those found in "bulk" databases such as the World Bank's World Development Indicators, OECD SOCX or other institutions that form part of the United Nations system broadly defined. Definitions of categories may vary too. The definition of social spending here is different from, for example, OECD's. The OECD SOCX definition for public social expenditure is as follows: social spending with financial flows controlled by General Government (different levels of government and social security funds), as social insurance and social assistance payments. Social benefits include cash benefits (e.g. pensions, income support during maternity leave and social assistance payments) and social services (e.g. childcare, care for the elderly and disabled). It therefore excludes education spending. 

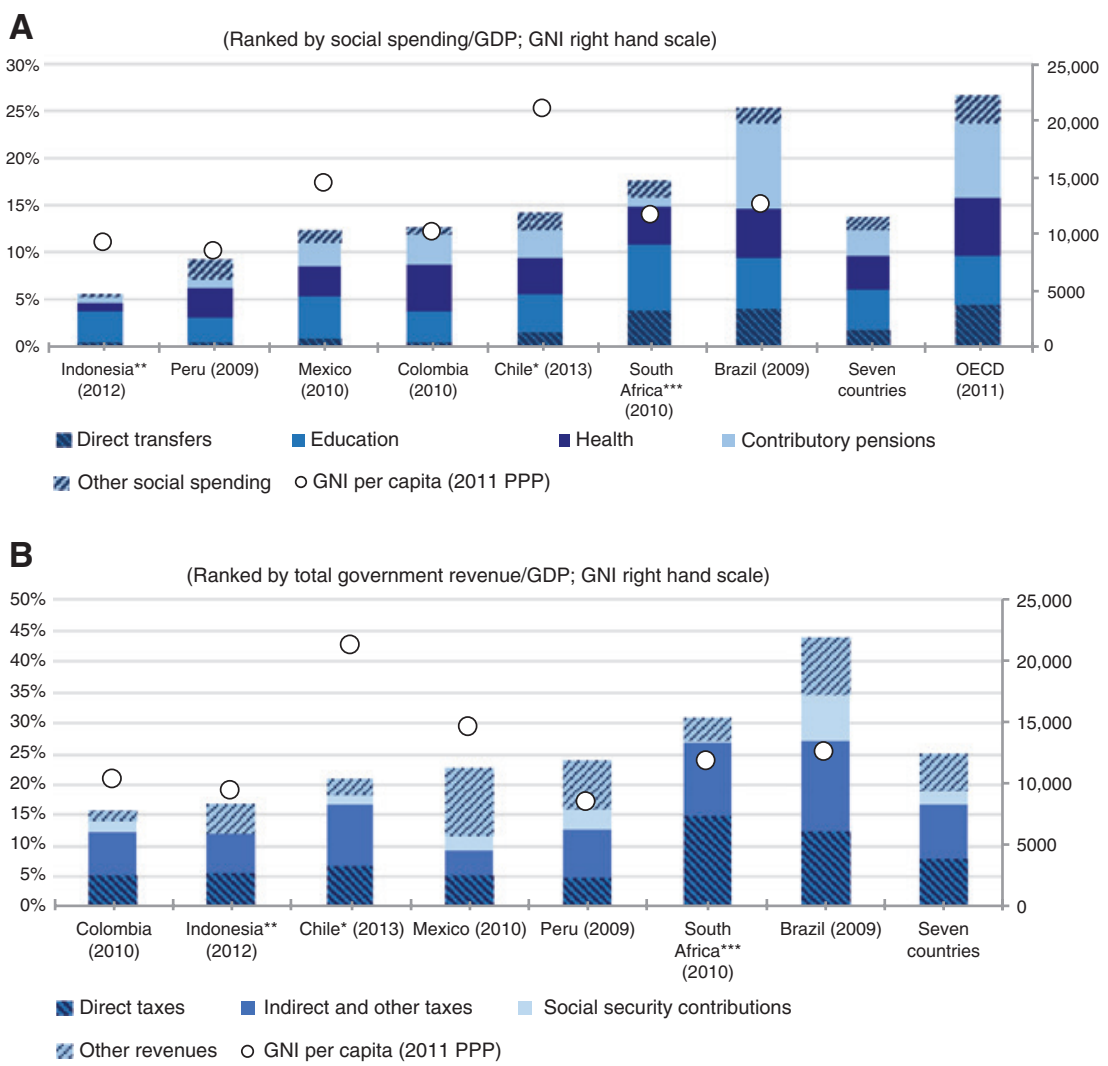

Figure 3: Size and composition of Government budgets (Circa 2010).

Panel A: Composition of social spending as a share of GDP; Panel B: Composition of total government revenues as a share of GDP.

Source: Author's calculations based on Brazil: Higgins and Pereira (2014); Chile: MartinezAguilar et al. (2016); Colombia: Lustig and Melendez (2015); Indonesia: Afkar et al. (2016); Mexico: Scott (2014); OECD: averages were provided by the organization itself and are for 2011; Peru: Jaramillo (2014); South Africa: Inchauste et al. (2015).

Note: Year of household survey in parenthesis. Data shown here is administrative data as reported by the studies cited above and the numbers do not necessarily coincide with those of the OECD databases (or other multilateral organizations). Gross National Income per capita on right axis is in 2011 PPP from World Development Indicators, July 10th, 2015: http://data. worldbank.org/indicator/NY.GNP.PCAP.PP.CD

*Chile only has a pay-as-you-go system for older workers and a fully funded system running since 1980 based on individual accounts.

**For Indonesia, the fiscal incidence analysis was carried out adjusting for spatial price differences. This adjustment, however, does not affect figures on this figure.

$\star \star \star T h e$ only contributory pensions in South Africa are for public servants who must belong to the Government Employees Pension Fund; they were not included in the analysis for South Africa and are not shown here. 
pensions (which together comprise close to 1 percent of GDP), Brazil has another noncontributory program called "Special Circumstances Pensions" (that covers idiosyncratic shocks such as accident at work, sickness and other related shocks) to which it devotes 2.3 percent of GDP. In South Africa, the largest program is the noncontributory old-age pension (1.3 percent of GDP) followed by the child grant program (1.1 percent of GDP). On the other end of the spectrum are Indonesia and Peru, where direct transfers represent only 0.4 percent of GDP (in both cases). Peru allocates relatively little to income redistribution through its signature cash transfer Juntos. In the case of Indonesia, at the time of the survey (2012), the government allocated much more of its resources to energy subsidies (3.7 percent of GDP) than cash transfers ( 0.4 percent of GDP).

On average, these seven countries spend 1.7 percent of GDP on direct transfers, 2.9 percent on pensions (includes contributory pensions only and not social pensions, which are part of direct transfers), 4.3 percent on education and 3.6 percent on health. Total social spending equals 13.9 percent of GDP. In comparison, the OECD countries (of which Chile and Mexico are members) on average spend 4.4 percent of GDP on direct transfers, 7.9 percent on pensions (includes contributory and social pensions), 5.3 percent on education and 6.2 percent on health. The average of total social spending is 26.7 percent of GDP, almost twice the average for the seven middle income countries. The largest difference occurs in direct transfers and contributory pensions. Direct transfers are almost three times as large, on average, in the OECD countries (even though the category does not include noncontributory pensions). ${ }^{16}$

The revenue collection patterns, as shown in Panel B, are heterogeneous as well. Mexico relies heavily on nontax revenues (from the state-owned oil company), followed by Brazil and Peru. In general, indirect taxes are a larger share of GDP, except for South Africa.

Given their size and structure of spending, Brazil and South Africa have the largest amount of resources at their disposal to engage in fiscal redistribution. At the other end of the spectrum are Colombia and Indonesia. Whether Brazil and South Africa achieve their higher redistributive potential, however, depends on how the burden of taxation and the benefits of social spending is distributed. This shall be discussed below. First, however, the next section presents a brief description of the fiscal incidence methodology utilized in the seven studies.

16 Figures for the seven countries are: Brazil (2009), Chile (2013), Colombia (2010), Indonesia (2012), Mexico (2010), Peru (2009) and South Africa (2010). OECD averages were provided by the organization itself and are for 2011. 


\section{Fiscal Incidence Analysis: Methodological Highlights $^{17}$}

Fiscal incidence analysis is used to assess the distributional impacts of a country's taxes and transfers. Essentially, fiscal incidence analysis consists of allocating taxes (personal income tax and consumption taxes, in particular) and public spending (social spending in particular) to households or individuals so that one can compare incomes before taxes and transfers with incomes after taxes and transfers. ${ }^{18}$ Transfers include both cash transfers and benefits in kind such as free government services in education and healthcare. Transfers also include consumption subsidies such as food, electricity and fuel subsidies.

As with any fiscal incidence study, let's start by defining the basic income concepts. Here there are four: market, disposable, consumable and final income. ${ }^{19}$ These income concepts are described below and summarized in Figure 4.

Market income ${ }^{20}$ is total current income before direct taxes, equal to the sum of gross (pre-tax) wages and salaries in the formal and informal sectors (also known as earned income), income from capital (dividends, interest, profits, rents, etc.) in the formal and informal sectors (excludes capital gains and gifts), consumption of own production, ${ }^{21}$ imputed rent for owner occupied housing, and private transfers (remittances, pensions from private schemes and other private transfers such as alimony).

Disposable income is defined as market income minus direct personal income taxes on all income sources (included in market income) that are subject to taxation plus direct government transfers (mainly cash transfers but can include near cash transfers such as food transfers, free textbooks and school uniforms).

Consumable income is defined as disposable income plus indirect subsidies (e.g. food and energy price subsidies) minus indirect taxes (e.g. value added taxes, excise taxes, sales taxes, etc.).

Final income is defined as consumable income plus government transfers in the form of free or subsidized services in education and health valued at average cost of provision ${ }^{22}$ (minus co-payments or user fees, when they exist).

17 This section is based on Lustig and Higgins (2013).

18 In addition to the studies cited here and other studies in www.commitmentoequity.org, see, for example, Förster and Whiteford (2009), Immervoll and Richardson (2011) and OECD (2011). 19 In the case of Indonesia, the surveys do not have income data so the incidence analysis is based on assuming consumption equals disposable income.

20 Market income is sometimes called primary or original income.

21 Except in the case of South Africa, whose data on auto-consumption (also called own-production or self-consumption) was not considered reliable.

22 See, for example, Sahn and Younger (2000). 


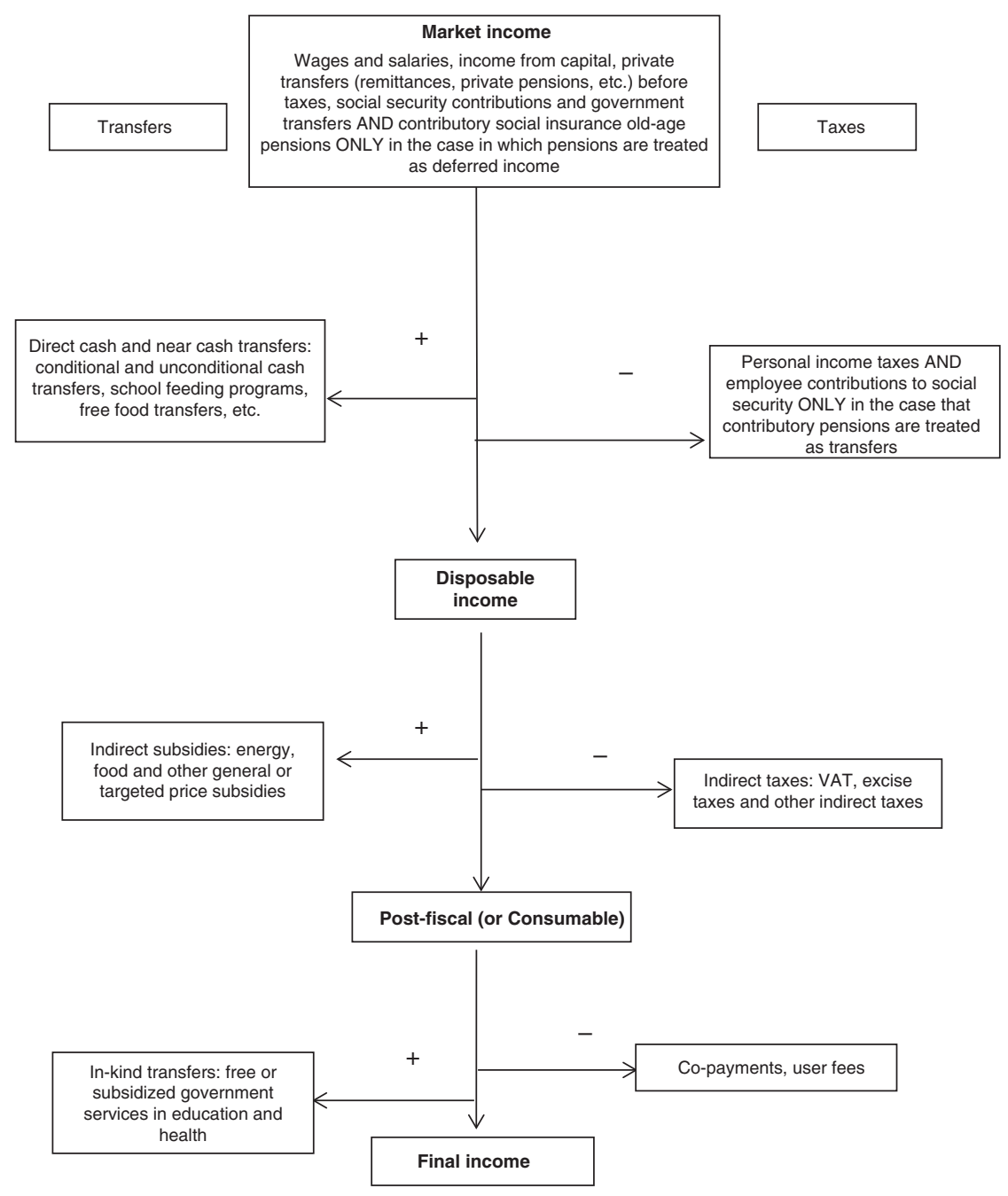

Figure 4: Basic income concepts.

One area in which there is no clear consensus is how pensions from a pay-as-yougo contributory system should be treated. Arguments exist in favor of both treating contributory pensions as deferred income ${ }^{23}$ or as a government transfer, especially in systems with a large subsidized component. ${ }^{24}$ Since this is an unresolved issue, the studies analyzed here present results for both methods. One scenario treats

23 Breceda et al. (2008); Immervoll et al. (2009).

24 Goñi et al. (2011); Immervoll et al. (2009); Lindert et al. (2006). 
social insurance contributory pensions (herewith called contributory pensions) as deferred income (which in practice means that they are added to market income to generate the original or "pre-fisc" income). The other scenario treats these pensions as any other cash transfer from the government. ${ }^{25}$ For consistency, when pensions are treated as deferred income, the contributions by individuals are included under savings (they are mandatory savings) while when they are treated as government transfers, the contributions are considered a direct tax.

It is important to note that the treatment of contributory pensions not only affects the amount of redistributive spending and how it gets redistributed, but also the ranking of households by original income or pre-fiscal income. For example, in the scenario in which contributory pensions are considered a government transfer, households whose main (or sole) source of income is pensions will have close to (or just) zero income before taxes and transfers and hence will be ranked at the bottom of the income scale. When contributory pensions are treated as deferred income, in contrast, households who receive contributory pensions will be placed at a (sometimes considerably) higher position in the income scale. Thus, the treatment of contributory pensions in the incidence exercise could have significant implications for the order of magnitude of the "pre-fisc" and "postfisc" inequality and poverty indicators.

In the construction of final income, the method for education spending consists of imputing a value to the benefit accrued to an individual of going to public school which is equal to the per beneficiary input costs obtained from administrative data: for example, the average government expenditure per primary school student obtained from administrative data is allocated to the households based on how many children are reported attending public school at the primary level. In the case of health, the approach was analogous: the benefit of receiving healthcare in a public facility is equal to the average cost to the government of delivering healthcare services to the beneficiaries. In the case of Colombia, however, the method used was to impute the insurance value to beneficiary households rather than base the valuation on utilization of healthcare services.

This approach to valuing education and healthcare services amounts to asking the following question: how much would the income of a household have to be increased if it had to pay for the free or subsidized public service (or the insurance value in the cases in which this applies to healthcare benefits) at the full cost to the government? Such an approach ignores the fact that consumers may value services quite differently from what they cost. Given the limitations of available data, however, the cost of provision method is the best one can do for

25 Immervoll et al. (2009) do the analysis under these two scenarios as well. 
now. ${ }^{26}$ For the readers who think that attaching a value to education and health services based on government costs is not accurate, the method applied here is equivalent to using a simple binary indicator of whether or not the individual uses the government service. . $^{2728}$

The welfare indicator used in the fiscal incidence analysis is income per capita, ${ }^{29}$ except for the case of Indonesia in which the welfare indicator was consumption-based (also in per capita) ${ }^{30}$ In Indonesia, the method was to assume that disposable income equals consumption and market income was generated "backwards" applying a "net to gross" conversion. ${ }^{31}$ Furthermore, the Indonesian survey does not include individuals with income levels beyond the threshold at which direct taxes begin to apply (see Afkar et al. 2016). In the data for South Africa, Free Basic Services are considered as direct transfers. ${ }^{32}$ The only contributory pensions in South Africa are for public servants who must belong to the Government Employees Pension Fund (GEPF). Since the government made no transfers to the GEPF in 2010/2011, there is no scenario in which contributory pensions are treated as a transfer. Also, survey data on own-consumption (which is part of market income) were not considered reliable in the case of South Africa (see Inchauste et al. 2015). In Chile, only has a pay-as-you-go system for older workers and a fully funded system running since 1980 based on individual accounts (Martinez-Aguilar et al. 2016). ${ }^{33}$

26 By using averages, it also ignores differences across income groups and regions: e.g. governments may spend less (or more) per pupil or patient in poorer areas of a country. Some studies in the CEQ project adjusted for regional differences. For example, Brazil's health spending was based on regional specific averages.

27 This is of course only true within a level of education. A concentration coefficient for total non-tertiary education, for example, where the latter is calculated as the sum of the different spending amounts by level, is not equivalent to the binary indicator method.

28 In order to avoid exaggerating the effect of government services on inequality, the totals for education and health spending in the studies reported here were scaled-down so that their proportion to disposable income in the national accounts are the same as those observed using data from the household surveys.

29 No adjustments were made for household composition or economies of scale. For Brazil, Higgins and Lustig (2016) analyze the impact of taxes and transfers using equivalized income.

30 In Indonesia, the fiscal incidence analysis was carried out adjusting for spatial price differences because they are considered to be very large.

31 See, for example, Immervoll and O’Donoghue (2001).

32 These Free Basic Services are delivered by municipal governments sometimes at zero cost and sometimes at a subsidized price. Given the difficulty in determining which case applies for households included in the survey, the analysis was carried out in both ways. Results in which the Free Basic Services are considered a subsidy are available upon request.

33 For details, see Lustig and Higgins (2013). 
The fiscal incidence analysis used here is point-in-time and does not incorporate behavioral or general equilibrium effects. That is, no claim is made that the original or market income equals the true counter-factual income in the absence of taxes and transfers. It is a first-order approximation that measures the average incidence of fiscal interventions. However, the analysis is not a mechanically applied accounting exercise. The incidence of taxes is the economic rather than statutory incidence. It is assumed that individual income taxes and contributions both by employees and employers, for instance, are borne by labor in the formal sector. Individuals who are not contributing to social security are assumed to pay neither direct taxes nor contributions. Consumption taxes are fully shifted forward to consumers. In the case of consumption taxes, the analyses take into account the lower incidence associated with own-consumption, rural markets and informality.

In general, fiscal incidence exercises are carried out using household surveys and this is what was done here. The surveys used in the country studies are the following: Brazil: Pesquisa de Orçamentos Familiares, 2009 (I); Chile: Encuesta de Caracterización Social (CASEN), 2013 (I); Colombia: Encuesta de Calidad de Vida, 2010 (I); Indonesia: Survei Sosial-Ekonomi Nasional, 2012 (C); Mexico: Encuesta Nacional de Ingreso y Gasto de los Hogares, 2010 (I); Peru: Encuesta Nacional de Hogares, 2009 (I); South Africa: Income and Expenditure Survey and National Income Dynamics Study, 2010-2011 (I). The description of how each income concept was constructed and which assumptions were made in each country can be found in the following references: Brazil (Higgins and Pereira 2014), Chile (Martinez-Aguilar et al. 2016), Colombia (Lustig and Melendez 2015), Indonesia (Afkar et al. 2016), Mexico (Scott 2014), Peru (Jaramillo 2014) and South Africa (Inchauste et al. 2015). ${ }^{34}$

\section{The Redistributive Effect of Fiscal Policy}

A typical indicator of the redistributive effect of fiscal policy is the difference between the market income Gini and the Gini for income after taxes and transfers. ${ }^{35}$ If the redistributive effect is positive (negative), fiscal policy is equalizing (unequalizing).

34 Note that empirically one often starts from a concept different from market income. In many income-based surveys, reported income corresponds (or is assumed to be) market income net of direct taxes. In consumption-based surveys, there is often no reported income at all. In those cases, the incidence analysis assumed that consumption is equivalent to disposable income.

35 All the theoretical derivations that link changes in inequality to the progressivity of fiscal interventions have been derived based on the so-called family of S-Gini indicators, of which the Gini coefficient is one case. See for example, Duclos and Araar (2006). While one can calculate the impact of fiscal policy on inequality using other indicators (and one should), it will not be possible to link them to the progressivity of the interventions. 
Figure 5 presents the Gini coefficient for market income and the other three income concepts shown in Figure 4: disposable, consumable and final income. ${ }^{36}$ In broad terms, disposable income measures how much income individuals may spend on goods and services (and save, including mandatory savings such as contributions to a public pensions system that is actuarially fair). Consumable income measures how much individuals are able to actually consume. For example, a given level of disposable income-even if consumed in full-could mean different levels of actual consumption depending on the size of indirect taxes and subsidies. Final income includes the value of public services in education and health if individuals would have had to pay for those services at the average cost to the government. Based on the fact that contributory pensions can be treated as deferred income or as a direct transfer, here all the calculations are presented for two scenarios: one with contributory pensions included in market income and another with them as government transfers. For consistency, remember that in the first scenario contributions to the system are treated as mandatory savings and in the second as a tax.

As can be observed, in Colombia, Indonesia and Peru, fiscal income redistribution is quite limited while in South Africa and Brazil, it is of a relevant magnitude. Mexico is in the middle of these two groups. One can observe that South Africa is the country that redistributes the most but it still remains the most unequal of all seven. It is interesting to note that although Brazil and Colombia start out with similar market income inequality, Brazil reduces inequality considerably while Colombia does not. Similarly, Mexico, Chile and Peru start out with similar levels of market income inequality but Mexico and Chile reduce inequality by more. Indonesia is the less unequal of all seven and fiscal redistribution is also the smallest in order of magnitude. The largest change in inequality occurs between consumable and final income. This is not surprising given the fact that governments spend more on education and health than on direct transfers and pensions. However, one should not make sweeping conclusions from this result because - as discussed above - in-kind transfers are valued at average government cost which is not really a measure of the "true" value of these services to the individuals who use them.

Panels A and B in Figure 5 show that the patterns of inequality decline are similar whether one looks at the scenario in which contributory pensions are considered deferred income (and, thus, part of market income) or with pensions as transfers. In Brazil and Colombia, and to a lesser extent in Indonesia, the redistributive effect is larger when pensions are treated as a transfer, while in Mexico and Peru it is somewhat lower.

36 Other measures of inequality such as the Theil index or the 90/10 ratio are available in the individual studies. Requests should be addressed directly to the authors. 


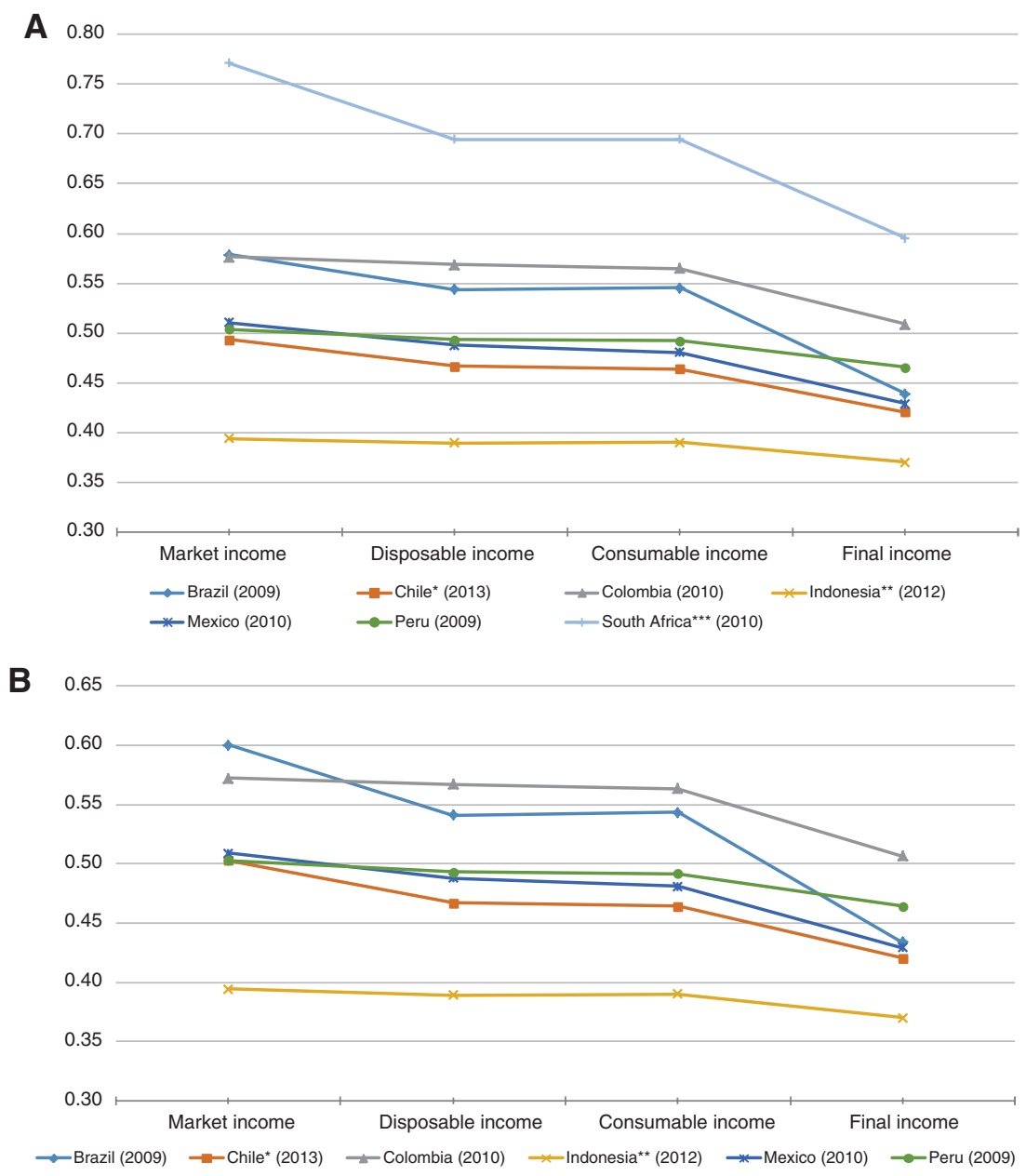

Figure 5: Fiscal policy and inequality (Circa 2010): Gini coefficient for market, disposable, consumable and final income.

Panel A: Contributory pensions as deferred income; Panel B: Contributory pensions as transfers. Source: Author's calculations based on Brazil: Higgins and Pereira (2014); Chile: MartinezAguilar et al. (2016); Colombia: Lustig and Melendez (2015); Indonesia: Afkar et al. (2016); Mexico: Scott (2014); Peru: Jaramillo (2014); South Africa: Inchauste et al. (2015). *Chile only has a pay-as-you-go system for older workers and a fully funded system running since 1980 based on individual accounts. Ginis for Chile are estimated using Total Income. Official figures of inequality are estimated using Monetary Income.

**For Indonesia, the fiscal incidence analysis was carried out adjusting for spatial price differences. This adjustment, however, does not affect figures on this figure.

***The only contributory pensions in South Africa are for public servants who must belong to the Government Employees Pension Fund; they were not included in the analysis for South Africa and are not shown here. The scenario for South Africa assumed free basic services are direct transfers. 
Table 2: Gini coefficient for pre-pension and post-pension market income (Circa 2010).

\begin{tabular}{|c|c|c|c|c|c|c|c|}
\hline & $\begin{array}{l}\text { Brazil } \\
(2009)\end{array}$ & $\begin{array}{l}\text { Chile* }^{*} \\
(2013)\end{array}$ & $\begin{array}{r}\text { Colombia } \\
(2010)\end{array}$ & $\begin{array}{r}\text { Indonesia** } \\
(2012)\end{array}$ & $\begin{array}{l}\text { Mexico } \\
(2008)\end{array}$ & $\begin{array}{r}\text { Peru } \\
(2009)\end{array}$ & $\begin{array}{r}\text { South Africa***} \\
(2010)\end{array}$ \\
\hline $\begin{array}{l}\text { Pension as \% } \\
\text { GDP }\end{array}$ & $9.06 \%$ & $2.93 \%$ & $3.14 \%$ & $0.76 \%$ & $2.58 \%$ & $0.90 \%$ & $0.97 \%$ \\
\hline $\begin{array}{l}\text { Gini market } \\
\text { income w/o } \\
\text { pensions }\end{array}$ & 0.5999 & 0.5028 & 0.5720 & 0.3944 & 0.5087 & 0.5025 & - \\
\hline $\begin{array}{l}\text { Gini market } \\
\text { income w/ } \\
\text { pensions }\end{array}$ & 0.5788 & 0.4936 & 0.5766 & 0.3942 & 0.5107 & 0.5039 & 0.7712 \\
\hline Change in \% & $3.6 \%$ & $1.9 \%$ & $-0.8 \%$ & $0.1 \%$ & $-0.4 \%$ & $-0.3 \%$ & - \\
\hline Change in ppts & 0.0211 & 0.0092 & -0.0046 & 0.0002 & -0.0019 & -0.0014 & - \\
\hline
\end{tabular}

Source: Author's calculations based on Brazil: Higgins and Pereira (2014); Chile: MartinezAguilar et al. (2016); Colombia: Lustig and Melendez (2015); Indonesia: Afkar et al. (2016); Mexico: Scott (2014); Peru: Jaramillo (2014); South Africa: Inchauste et al. (2015).

Year of household survey in parenthesis.

*Chile only has a pay-as-you-go system for older workers and a fully funded system running since 1980 based on individual accounts. Ginis for Chile are estimated using Total Income. Official figures of inequality are estimated using Monetary Income.

**For Indonesia, the fiscal incidence analysis was carried out adjusting for spatial price differences. ***The only contributory pensions in South Africa are for public servants who must belong to the Government Employees Pension Fund. Since the government made no transfers to the GEPF in 2010/2011, there is no scenario in which contributory pensions are treated as a transfer. The scenario for South Africa assumed free basic services are direct transfers.

i. Are Contributory Pensions Equalizing or Unequalizing?

One common question is whether contributory pensions are equalizing or unequalizing. Table 2 shows the Gini coefficients with market income with and without contributory pensions. As one can observe, contributory pensions are equalizing in Brazil, Chile and Indonesia and slightly unequalizing in Mexico, Peru and Colombia. ${ }^{37}$ The fact that the pattern depends on the country is interesting. Statements such as "pensions are regressive" (by that meaning that they are unequalizing) are not universally true.

ii. The redistributive effect of fiscal policy: do more unequal countries redistribute more?

Income redistribution tends to be higher in more unequal countries to start with: redistribution is considerable higher in countries with higher market

37 Note that this is not equivalent to estimating the marginal contribution of pensions assuming all the other fiscal interventions are in place. 

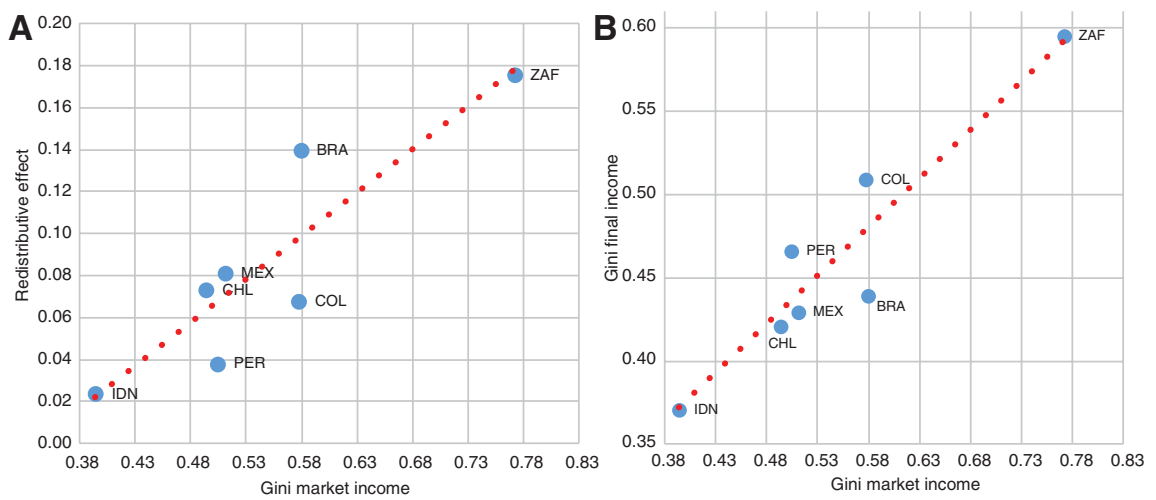

Figure 6: Inequality and redistribution, 2010.

Panel A: Redistribution and market income inequality; Panel B: Final income inequality and market income inequality.

Source: Lustig (2015a).

Note: Red line is the trends. Redistribution measures the difference between Gini of market and final incomes.

*Chile only has a pay-as-you-go system for older workers and a fully funded system running since 1980 based on individual accounts. Ginis for Chile are estimated using Total Income. Official figures of inequality are estimated using Monetary Income.

**For Indonesia, the fiscal incidence analysis was carried out adjusting for spatial price differences.

***The only contributory pensions in South Africa are for public servants who must belong to the Government Employees Pension Fund. Since the government made no transfers to the GEPF in $2010 / 2011$, there is no scenario in which contributory pensions are treated as a transfer. The scenario for South Africa assumed free basic services are direct transfers.

income inequality such as South Africa, Brazil, Mexico and Chile than in countries with relatively lower inequality, such as Indonesia and Peru (see Figure 6, Panel A). Among these countries, Colombia stands as an outlier with a rather low degree of redistribution given its high level of market income inequality. Previous studies also generally suggest a positive correlation between market income inequality and measures of redistribution. Lustig (2015b) finds this in an analysis for 13 developing countries. An OECD study (2011, Chapter 7) illustrates that more market income inequality tends to be associated with higher redistribution, for a sub-set of OECD countries, both within countries (over time) and across countries.

Differences in redistribution change the relative ranking of countries by inequality level. Figure 6, Panel B displays the levels of income inequality before (horizontal axis) and after (vertical axis) accounting for fiscal policies. Fiscal policies reduce inequality in all countries and South Africa continues to be the most unequal country and Indonesia the least unequal country based on income 


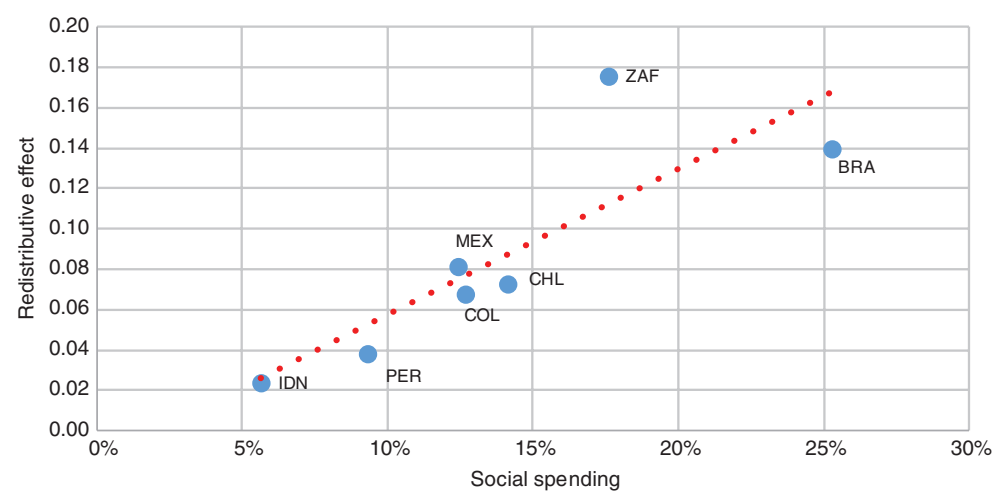

Figure 7: Redistribution and social spending, 2010.

Source: Lustig (2015a).

Note: Trend line in red. Social Spending includes all direct transfers, all pensions and spending on education and health. Data shown here is administrative data as reported by the studies of each country and the numbers do not necessarily coincide with those of the OECD databases (or other multilateral organizations).

*Chile only has a pay-as-you-go system for older workers and a fully funded system running since 1980 based on individual accounts. Ginis for Chile are estimated using Total Income. Official figures of inequality are estimated using Monetary Income.

** For Indonesia, the fiscal incidence analysis was carried out adjusting for spatial price differences. $\star \star \star$ The only contributory pensions in South Africa are for public servants who must belong to the Government Employees Pension Fund. Since the government made no transfers to the GEPF in $2010 / 11$, there is no scenario in which contributory pensions are treated as a transfer. The scenario for South Africa assumed free basic services are direct transfers.

before or after fiscal policy. However, due to lower redistribution, Colombia and Peru end up being more unequal than Brazil, Chile and Mexico, once fiscal policies are considered.

As expected, the level of income redistribution and the size of the budget allocated to social spending (as a share of GDP) are associated. However, differences across countries suggest that institutional factors such as the composition and design of such policies and their interaction with socio-economic circumstances also affect the level of redistribution. Figure 7 presents the level of redistribution and social spending measured in the CEQ database. Redistribution is considerably larger in countries with high social spending, such as Brazil and South Africa, than in Colombia, Indonesia and Peru, where social spending is more limited. Given the level of social spending, income redistribution is particularly high in South Africa.

iii. Redistributive Effect: A Comparison with Advanced Countries

How do these seven middle income countries compare with the fiscal redistribution that occurs in advanced countries? Although the methodology is somewhat 
different, one obvious comparator is the analysis produced by EUROMOD for the 27 countries in the European Union. ${ }^{38}$ Given that EUROMOD covers only direct taxes, contributions to social security and direct transfers, the comparison can be done for the redistributive effect from market to disposable income. A comparison is also made with the United States. ${ }^{39}$

There are three important differences between the advanced countries and the seven middle income ones analyzed here. First, market income inequality tends to be somewhat higher for the middle income countries. ${ }^{40}$ However, the difference is most striking when pensions are treated as transfers. The average Gini coefficient for the seven middle income countries for the scenario in which pensions are treated as deferred income and the scenario in which they are considered transfers is 54.7 and 51.3 percent, respectively. In contrast, in the EU, the corresponding figures are 38.2 and 49.9 percent, respectively; and in the US, they are, 44.6 and 48.1, respectively. One important aspect to note, however, is that in the EU, pensions include both contributory and noncontributory social pensions while in the middle income countries and the US, the category of pensions includes only contributory pensions. If the latter would include noncontributory pensions as part of market income, the Gini would be lower.

Second, as expected and shown in Figure 8, the redistributive effect is larger in the EU countries and, to a lesser extent, in the United States (except for South Africa, whose redistributive effect is larger than in the US when pensions are part of market income). In the seven middle income countries, whether pensions are treated as deferred income or a transfer makes a relatively small difference. This is not the case in the EU countries where the difference is huge. In the EU, the redistributive effect with contributory pensions as deferred income and contributory pensions as a transfer is 9.2 and 20.8 Gini points, respectively. In the United States, the numbers are less dramatically different: 7 and 10.9, respectively. In the seven middle income countries, the numbers are 2.6 and 2.3 Gini points, respectively. Clearly, the assumption made about how to treat incomes from pensions, again, makes a big difference.

Third, in no European country nor in the United States, contributory pensions are unequalizing. On the contrary, vis-à-vis market income without pensions, they exert a large equalizing force in the EU and less so in the US. Using data for 2010, for example, the difference between the market income Gini and

38 The data for EU 27 is from EUROMOD statistics on Distribution and Decomposition of Disposable Income, accessed at http://www.iser.essex.ac.uk/euromod/statistics/ using EUROMOD version no. G2.0. The year 2010 was used.

39 Higgins and Lustig (2016).

40 South Africa pulls the average up but Indonesia pulls it down. 


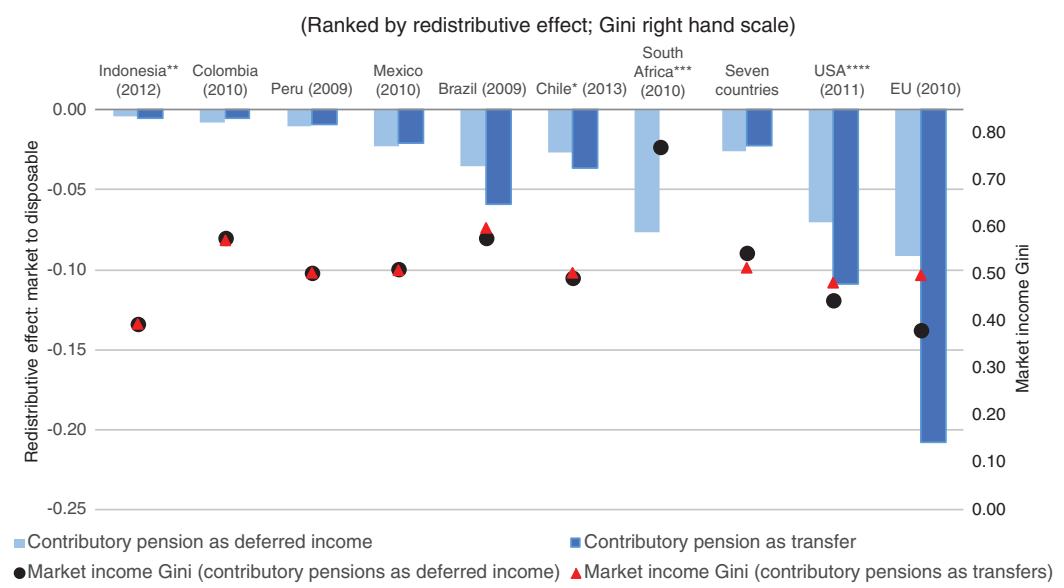

Figure 8: Redistributive effect: Brazil, Chile, Colombia, Indonesia, Mexico, Peru, South Africa, Eu and The United States: Change in Gini points: market to disposable income; Circa (2010). Source: Author's calculations based on Brazil: Higgins and Pereira (2014); Chile: Martinez-Aguilar et al. (2016); Colombia: Lustig and Melendez (2015); European Union: EUROMOD statistics on Distribution and Decomposition of Disposable Income, accessed at http://www.iser.essex. ac.uk/euromod/statistics/ using EUROMOD version no. G2.0. Indonesia: Afkar et al. (2016); Mexico: Scott (2014); Peru: Jaramillo (2014); South Africa: Inchauste et al. (2015). United States: Higgins et al. (2015).

Note: Year of household survey in parenthesis. For definition of income concepts see the Section on methodological highlights in text.

* Ginis for Chile are estimated using Total Income. Official figures of inequality are estimated using Monetary Income.

**For Indonesia, the fiscal incidence analysis was carried out adjusting for spatial price differences.

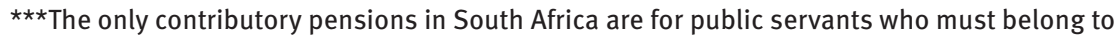
the Government Employees Pension Fund. Since the government made no transfers to the GEPF in $2010 / 2011$, there is no scenario in which contributory pensions are treated as a transfer. The scenario for South Africa assumed free basic services are direct transfers.

$\star \star \star \star T h e ~ G i n i ~ c o e f f i c i e n t s$ for the United States are for equivalized income.

the market income Gini plus pensions is 11.6 percentage points in the EU and 3.5 in the United States. As we saw above, in the seven middle income countries pensions are not always equalizing.

iv. Measuring the Contribution of Taxes and Transfers ${ }^{41}$

Suppose one observes that fiscal policy has an equalizing effect. Can one measure the influence of specific taxes (direct vs. indirect, for example) or transfers (direct transfers vs. indirect subsidies or in-kind transfers, for example) on the

41 This section is based on Lustig et al. (forthcoming). 
Table 3: Lambert's conundrum.

\begin{tabular}{lrrrrr}
\hline & $\mathbf{1}$ & $\mathbf{2}$ & $\mathbf{3}$ & $\mathbf{4}$ & Total \\
\hline Original income $x$ & 10 & 20 & 30 & 40 & 100 \\
Tax liability $\mathrm{t}(\mathrm{x})$ & 6 & 9 & 12 & 15 & 42 \\
Benefit level b(x) & 21 & 14 & 7 & 0 & 42 \\
Post-benefit income & 31 & 34 & 37 & 40 & 142 \\
Final income & 25 & 25 & 25 & 25 & 100 \\
\hline
\end{tabular}

Source: Lambert (2001), Table 11.1: p. 278.

observed result? ${ }^{42}$ A fundamental question in the policy discussion is whether a particular fiscal intervention (or a particular combination of them) is equalizing or unequalizing. In a world with a single fiscal intervention (and no reranking), it is sufficient to know whether a particular intervention is progressive or regressive to give an unambiguous response using the typical indicators of progressivity such as the Kakwani index. ${ }^{43}$ In a world with more than one fiscal intervention (even in the absence of reranking), this one-to-one relationship between the progressivity of a particular intervention and its effect on inequality breaks down. As Lambert (2001) so eloquently demonstrates it, depending on certain characteristics of the fiscal system, a regressive tax can exert an equalizing force over and above that which would prevail in the absence of that regressive tax. ${ }^{44}$

An example borrowed from Lambert (2001, Table 11.1: p. 278) helps illustrate this point in the case of a regressive tax (Table 3). ${ }^{45}$ The table below shows that “...taxes may be regressive in their original income... and yet the net system may exhibit more progressivity" than the progressive benefits alone. The redistributive effect for taxes only in this example is equal to -0.0517 , highlighting their regressivity. ${ }^{46}$ Yet, the redistributive effect for the net fiscal system is 0.25 , higher than the redis-

42 Note that the influence of specific interventions may not be equalizing, even if the overall effect of the net fiscal system is.

43 The Kakwani index for taxes is defined as the difference between the concentration coefficient of the tax and the Gini for market income. For transfers, it is defined as the difference between the Gini for market income and the concentration coefficient of the transfer. See, for example, Kakwani (1977).

44 See Lambert (2001), pp. 277 and 278. Also, for a derivation of all the mathematical conditions that can be used to determine when adding a regressive tax is equalizing or when adding a progressive transfer is unequalizing, see Lustig et al. (forthcoming).

45 Lambert (2001) The Distribution and Redistribution of Income. Third Edition. Manchester University Press.

46 Since there is no reranking, the R-S equals the difference between the Ginis before and after the fiscal intervention. 
tributive effect for benefits only equal to 0.1972. If taxes are regressive vis-à-vis the original income but progressive with respect to the less unequally distributed post-transfers income, regressive taxes exert an equalizing effect over and above the effect of progressive transfers. ${ }^{47}$

Note that Lambert's conundrum is not equivalent to the well-known (and frequently repeated) result that efficient regressive taxes can be fine as long as, when combined with transfers, the net fiscal system is equalizing. ${ }^{48}$ The surprising aspect of Lambert's conundrum is that a net fiscal system with a regressive tax (vis-à-vis market) is more equalizing than without it. ${ }^{49}$

The implications of Lambert's "conundrum" 50 in real fiscal systems are quite profound. It means that in order to determine whether a particular intervention (or, a particular policy change) is inequality increasing or inequality reducingand by how much - one must resort to numerical calculations that include the whole system. As Lambert mentions, his example is "not altogether farfetched:"51 Two renowned studies in the 1980s found this type of result for the US and the UK..$^{52}$ It also made its appearance in a 1990s study for Chile. ${ }^{53}$ In the present analysis, as shall be seen below, Lambert's conundrum is found for indirect taxes in the cases of Chile and to a smaller extent in South Africa. This counter-intuitive result is the consequence of path dependency: a particular tax can be regressive

47 Note that Lambert uses the term progressive and regressive differently than other authors in the theoretical and empirical incidence analysis literature. Thus, he calls "regressive" transfers that are equalizing. See definitions in earlier chapters of his book.

48 As Higgins and Lustig (2016) mention, "efficient taxes that fall disproportionately on the poor, such as a noexemption value added tax, are often justified with the argument that 'spending instruments are available that are better targeted to the pursuit of equity concerns' (Keen and Lockwood, 2010: p. 141. Similarly, Engel et al. (1999: p. 186) assert that 'it is quite obvious that the disadvantages of a proportional tax are moderated by adequate targeting' of transfers, since 'what the poor individual pays in taxes is returned to her.' Ebrill et al. (2001: p. 105) argue that 'a regressive tax might conceivably be the best way to finance pro-poor expenditures, with the net effect being to relieve poverty'."

49 It can also be shown that if there is reranking, a pervasive feature of net tax systems in the real world, making a tax (or a transfer) more progressive can increase post-tax and transfers inequality. In Lambert's example, regressive taxes not only enhance the equalizing effect of transfers, but making taxes more progressive (i.e. more disproportional in the Kakwani sense) would result in higher(!) inequality; any additional change (towards more progressivity) in taxes or transfers would just cause reranking and an increase in inequality.

50 This is Lambert's choice of words (p. 278).

51 Quotes are from Lambert, op. cit., p. 278.

52 O'Higgins and Ruggles (1981) for the UK and Ruggles and O'Higgins (1981) for the US.

53 Engel et al. (1999). Although the authors did not acknowledge this characteristic of the Chilean system in their article, in a recent interaction with the lead author, it was concluded that the Chilean system featured regressive albeit equalizing indirect taxes. 
vis-à-vis market income but progressive vis-à-vis the income that would prevail if all the other fiscal interventions were already in place.

There are several ways of calculating the contribution of a particular fiscal intervention to the change in inequality (or poverty) taking account of path dependency. The most commonly used in the literature are the marginal contribution and the sequential contribution. A less commonly used measure is the total average contribution. The total average contribution is calculated by considering all the possible paths and taking, for example, the so-called Shapley value. ${ }^{54}$ The sequential contribution is calculated as the difference between inequality indicators with fiscal interventions ordered in a path according to their institutional design..$^{55}$ For example, if direct transfers are subject to taxation, the sequential contribution of personal income taxes is the difference between market income plus transfers and market income plus transfers and minus personal income taxes. The marginal contribution of a tax (or transfer) is calculated by taking the difference between the inequality indicator without the tax (or transfer) and with it. ${ }^{56}$ For example, the marginal contribution of indirect taxes is the difference between the Gini for consumable income plus indirect taxes (i.e. consumable income without the indirect taxes) and consumable income. Given the uncertainties that surround choosing the correct institutional path, this paper uses the marginal contribution method. In addition, the marginal contribution has a straightforward policy interpretation because it is equivalent to asking the question: what would inequality be if the system did not have a particular tax (or transfer) or if a tax (or transfer) was modified? Would inequality be higher, the same or lower with the tax (or transfer) than without it? ${ }^{57}$

Figure 9 shows the marginal contribution for four of the countries and for two net fiscal systems: from market to disposable income and from market to

54 For an analysis of the Shapley value and its properties see, for example, Shorrocks (2013). 55 OECD (2011) used this method, for example.

56 The marginal contribution should not be confused with the marginal incidence, the latter being the incidence of a small change in spending. The marginal contribution is not a derivative. Note that, because of path dependency, adding up the marginal contributions of each intervention will not be equal to the total change in inequality. Clearly, adding up the sequential contributions will not equal the total change in inequality either. An approach that has been suggested to calculate the contribution of each intervention in a way that they add up to the total change in inequality, is to use the Shapley value. The studies analyzed here do not have estimates for the latter.

57 Note that if certain fiscal interventions come in bundles (e.g. a tax that only kicks in if a certain transfer is in place), the marginal contribution can be calculated for the net tax (or the net benefit) in question. 
A

(Ranked by marginal contribution of direct transfers)

0.09

0.08

0.0768

0.07

0.06

0.05

0.04

0.03

0.0268

0.02

0.01

0.00

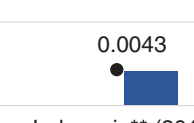

0.0079

$\bullet$

Indonesia** (2012) Colombia (2010) Chile* (2013) South Africa ${ }^{\star \star \star}(2010)$

$-0.01$

Direct taxes

- Direct transfers

- Redistributive effect

B

0.09

(Ranked by marginal contribution of direct transfers)

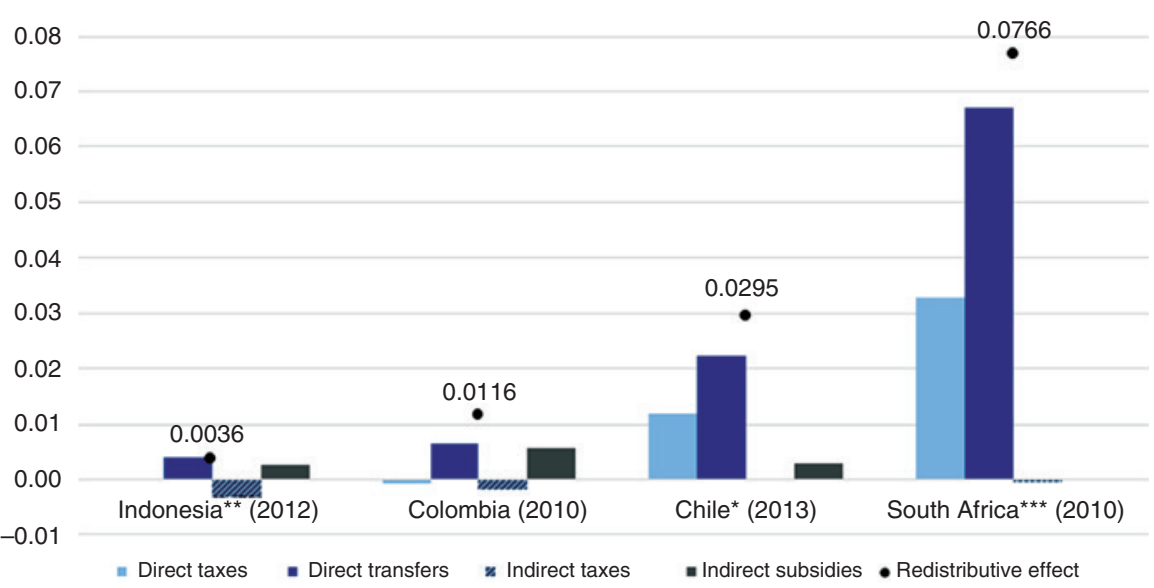


Figure 9: Marginal contribution of taxes and transfers (Circa 2010): pensions and market income.

Panel A: Redistributive effect from market to disposable income; Panel B: Redistributive effect from market to consumable income.

Source: Author's calculations based on Chile: Martinez-Aguilar et al. (2016); Colombia: Lustig and Melendez (2015); Indonesia: Afkar et al. (2016); South Africa: Inchauste et al. (2015).

Note: The Redistributive Effect (Black dot) is measured in Gini points and equals the difference between market income Gini and disposable income Gini (panel A) and between market income Gini and consumable income Gini (panel B). The Marginal Contribution (bars) is measured in Gini points and equals the difference between the Gini coefficient with the intervention of interest (with all the others in place) and the Gini coefficient without it (with all the others in place). Fiscal interventions that do not apply to a certain country are left blank.

*Chile only has a pay-as-you-go system for older workers and a fully funded system running since 1980 based on individual accounts.

**The Indonesian survey does not include individuals beyond the income at which direct taxes begin to apply, this scenario uses a consumption based survey.

***The South Africa scenario assumes Free Basic Services as direct transfers. The fiscal incidence analysis for South Africa does not include a scenario with contributory pensions as transfers.

consumable income. Both are presented because the existing fiscal redistribution studies frequently stop at direct taxes and direct transfers. ${ }^{58}$ The numbers in this figure were calculated subtracting the Gini of disposable (consumable) income to the Gini of disposable (consumable) income without the particular fiscal intervention. Note that an equalizing (unequalizing) effect is presented with a positive (negative) sign. ${ }^{59}$ The first result to note is that direct taxes and direct transfers are, as expected, always equalizing whether one calculates their marginal contribution with respect to disposable income or consumable income. ${ }^{60}$ Direct transfers exert a particularly high equalizing force in South Africa. ${ }^{61}$

The second result to note is that the marginal contribution of direct transfers is always higher than the marginal contribution of direct taxes. The third result

58 For example, the data published by EUROMOD, op cit.

59 Note that for the reasons mentioned in the paragraph immediately above, one cannot compare the orders of magnitude between categories of income.

60 Although not shown here, the same is true for in-kind transfers. These are not shown because the marginal contribution is identical to the sequential contribution presented in Figure 4.1 given that in-kind transfers are added at the end.

61 Note that one cannot compare orders of magnitude between interventions in an exact way because one drawback of the marginal contribution method is that the sum of all the marginal contributions is not equal to the total redistributive effect. 
to note is that the effect of indirect taxes is not always unequalizing. The marginal contribution is equalizing in the case of Chile and neutral in the case of South Africa. More interesting still is the fact that indirect taxes in Chile are regressive the Kakwani coefficients for indirect taxes is -0.03 - and yet equalizing. That is, in this country one finds the counter-intuitive effect known as Lambert's conundrum: a regressive tax can be equalizing (or neutral). Finally, the fourth result to note is that indirect subsidies are equalizing or neutral.

\section{Fiscal Policy and the Poor}

The above discussion has concentrated on the impact of fiscal policy on inequality. As important is the impact of fiscal policy on poverty. In particular, because the results not necessarily go in the same direction: i.e. an inequality reducing fiscal system could be poverty increasing. The effect of fiscal policy on poverty can be measured using the typical indicators such as the headcount ratio for market income and income after taxes and transfers. Another measure that one can use to assess the impact of fiscal policy on the poor is the extent to which market income poor end up being net payers to the fiscal system in cash terms (leaving out in-kind services).

When both direct and indirect taxes are included and using the $\$ 2.50 \mathrm{ppp}$ a day poverty line ${ }^{62}$ fiscal policy reduces the headcount ratio in Chile, Colombia, Indonesia, Mexico, Peru and South Africa (Figure 10). ${ }^{63}$ However, there is a startling result. In the scenario in which pensions are considered deferred income, while Brazil's poverty rates declines as a result of direct transfers (not shown in the figure), the effect of consumption taxes is such that consumable income poverty is higher than market income poverty. This is clearly the consequence of its tax system in which basic foodstuff such as rice and beans end up being heavily taxed. ${ }^{64}$ This is a worrisome result. Poverty should not be higher as a result of fiscal policy. Note that Brazil shows this feature despite the fact that the

62 The $\$ 2.50$ ppp a day poverty line is considered to be a reasonable international extreme poverty line for middle-income countries: for example, in the case of Latin America, this poverty line is close to the average of the local extreme poverty lines.

63 Chile's result is particularly high because market income poverty is lower in Chile than in the other countries. Thus, a similar change in percentage points represents a large change when measured in percentage change as done in Figure 9 above.

64 See Higgins and Pereira (2014). 


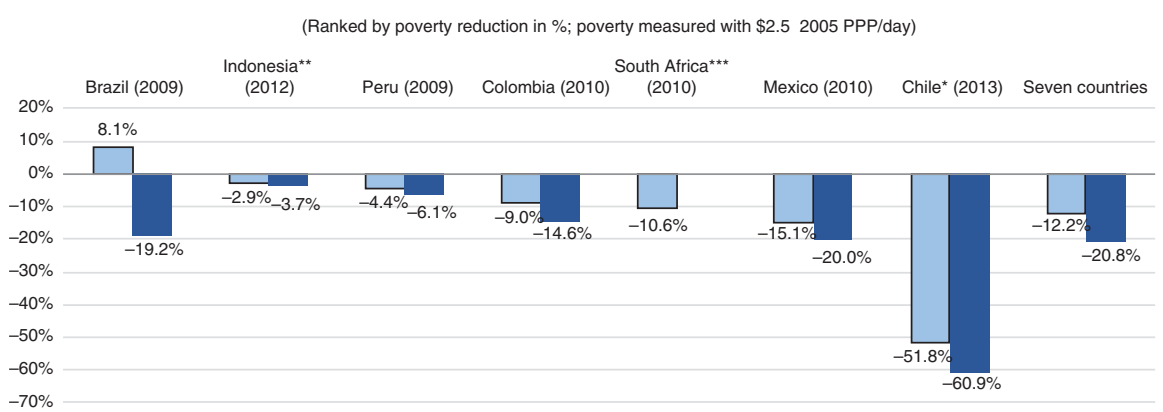

W Contributory pensions as deferred income Contributory pensions as transfer

Figure 10: Fiscal policy and poverty reduction (Circa 2010): change in headcount ratio from market to consumable income for contributory pensions as deferred income and as transfers; in \%.

Source: Author's calculations based on Brazil: Higgins and Pereira (2014); Chile: MartinezAguilar et al. (2016); Colombia: Lustig and Melendez (2015); Indonesia: Afkar et al. (2016); Mexico: Scott (2014); Peru: Jaramillo (2014); South Africa: Inchauste et al. (2015).

Notes: Poverty is measured with the international poverty line of US $\$ 2.50 \mathrm{ppp} /$ day (with the $2005 \mathrm{ppp}$ ). Countries are ranked by the change in poverty for the scenario where contributory pensions are treated as deferred income.

*Chile only has a pay-as-you-go system for older workers and a fully funded system running since 1980 based on individual accounts.

${ }^{*}$ Data for Indonesia is consumption-based and income-based for the rest.

$\star \star \star * T h e$ South Africa scenario assumes Free Basic Services as direct transfers. The fiscal incidence analysis for South Africa does not include a scenario with contributory pensions as transfers, hence it is not shown above.

net fiscal system (even without including in-kind transfers) reduces inequality. This emphasizes the fact that the impact of fiscal interventions on inequality and poverty should be studied separately.

When analyzing the impact of fiscal interventions on living standards, it is useful to distinguish between the net benefits in cash from the benefits received in the form of free government services in education and health. The cash component is measured by consumable income. The level of consumable income will tell whether the government has enabled an individual to be able to purchase private goods and services above his or her original market income.

In principle, it would be desirable for the poor - especially the extreme poor - to be net receivers of fiscal resources in cash so that poor individuals can buy/consume the minimum amounts of food and other essential goods imbedded in the selected poverty line. Figure 11 shows at which market income category, individuals - on average - become net payers to the fiscal system (again, this calculation only takes into account direct transfers in cash or near cash such as 

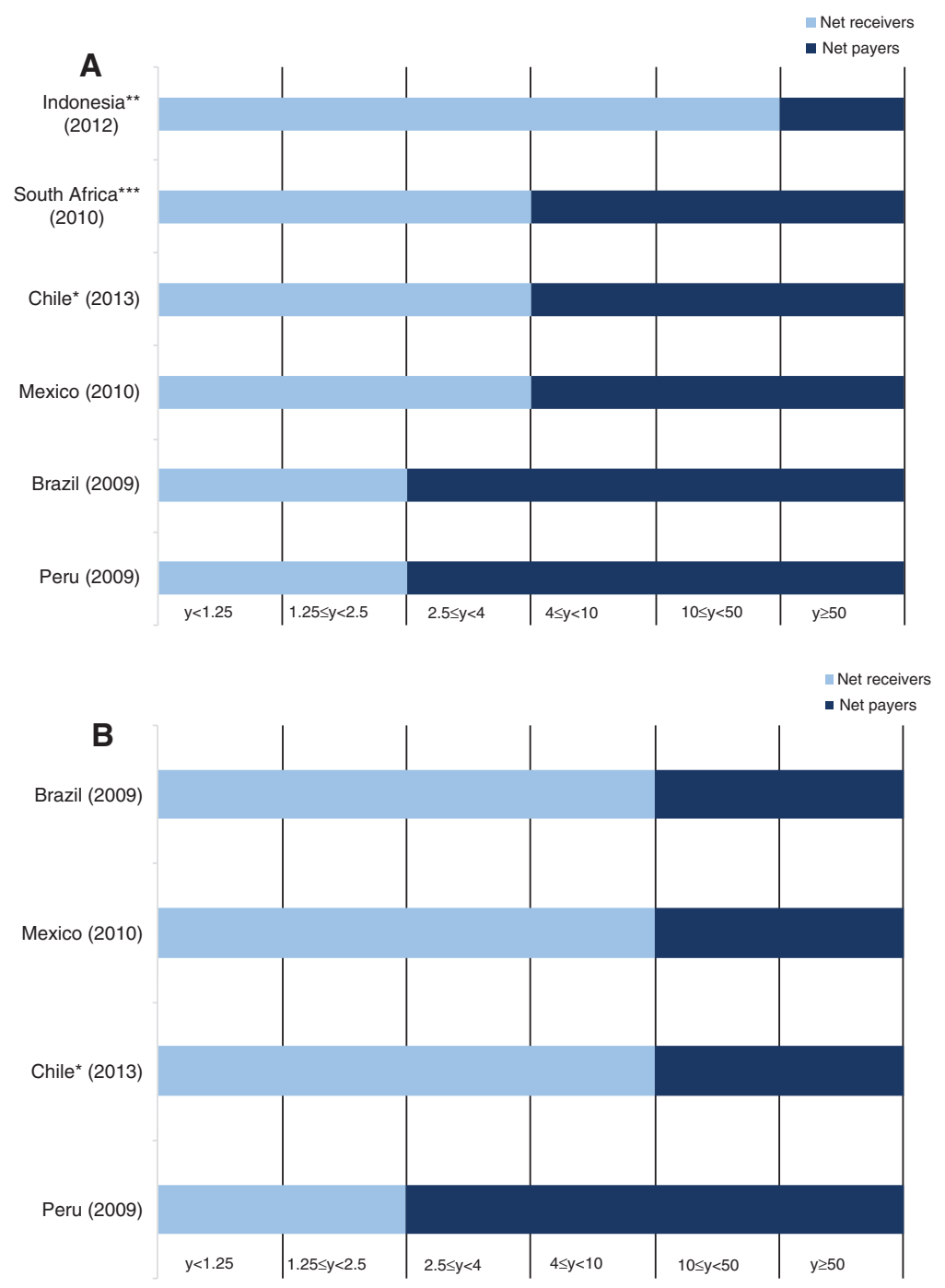

food). ${ }^{65}$ In Brazil and Peru net payers to the fiscal system begin in the income category \$US2.50-\$US4/day in purchasing power parity. That is, in the group classified as moderately poor. In the case of South Africa, Chile and Mexico, the net

65 Note that this graph presents a nonanonymous result: it looks at the extent to which the market income poor become net payers to the fiscal system on average. This information cannot be extrapolated from the typical poverty measures where winners and losers are not tracked. 
Figure 11: Net payers to the fiscal system (Circa 2010).

Panel A: Contributory pensions as deferred income; Panel B: Contributory pensions as transfers. Source: Author's calculations based on Brazil: Higgins and Pereira (2014); Chile: MartinezAguilar et al. (2016); Colombia: Lustig and Melendez (2015); Indonesia: Afkar et al. (2016); Mexico: Scott (2014); Peru: Jaramillo (2014); South Africa: Inchauste et al. (2015).

Note: Year of household survey in parenthesis. The income categories are based on López-Calva and Ortiz-Juárez (2014) and Ferreira et al. (2012).

*Chile only has a pay-as-you-go system for older workers and a fully funded system running since 1980 based on individual accounts.

**For Indonesia, the fiscal incidence analysis was carried out adjusting for spatial price differences.

$\star \star \star$ The results for South Africa are for the scenario in which Free Basic Services are considered a direct transfer.

payers start in the group known as "vulnerable." In Indonesia, only the "rich" are net payers to the fiscal system (on average). ${ }^{66}$ If contributory pensions are considered a government transfer (not shown), net payers to fiscal system start in the "middle class" in Brazil, Chile and Mexico and in Peru, they start in the group named as moderately poor. ${ }^{67}$

These results are the consequence of a variety of factors. In the case of Brazil, it is the consequence of consumption taxes on basic foodstuffs that wipe out the benefits from direct transfers such as Bolsa Familia for a considerable number of the market income poor. In the case of Indonesia, direct taxes start at income levels that are higher than the highest income in the survey and the indirect taxes are not high; in addition, the energy subsidies in Indonesia, although not targeted to the poor in particular, do help the poor as well as the "vulnerable" and "middle-class" groups.

\section{Education and Health Spending ${ }^{68}$}

To what extent are the poor benefitting from government spending on education and health? The pro-poorness of public spending on education and health here is

66 These income categories are based on López-Calva and Ortiz-Juárez (2014) and Ferreira et al. (2012).

67 For Colombia and Peru, information for the case with pensions as government transfers is not available. The only contributory pensions in South Africa are for public servants who must belong to the Government Employees Pension Fund. Since the government made no transfers to the GEPF in 2010/2011, there is no scenario in which contributory pensions are treated as a transfer. 68 Section based on Lustig (2015b). 
measured using concentration coefficients (also called quasi-Ginis). ${ }^{69}$ In keeping with conventions, spending is defined as regressive whenever the concentration coefficient is higher than the Gini for market income. When this occurs, it means that the benefits from that spending as a share of market income tend to rise with market income. ${ }^{70}$ Spending is progressive whenever the concentration coefficient is lower than the Gini for market income. This means that the benefits from that spending as a share of market income tend to fall with market income. Within progressive spending, spending is neutral in absolute terms - spending per capita is the same across the income distribution-whenever the concentration coefficient is equal to zero. Spending is defined as pro-poor whenever the concentration coefficient is not only lower than the Gini but also its value is negative. Pro-poor spending implies that the per capita government spending on the transfer tends to fall with market income. ${ }^{71}$ Any time spending is pro-poor or neutral in absolute terms, by definition it is progressive. The converse, of course, is not true. ${ }^{72}$ The taxonomy of transfers is synthesized in Figure 12.

A clarification is in order. In the analysis presented here, households are ranked by per capita market income, and no adjustments are made to their size because of differences in the composition by age and gender. In some analyses, the pro-poorness of education spending, for example, is determined using children - not all members of the household-as the unit of analysis. Because poorer families have, on average, a larger number of children, the observation that concentration curves are pro-poor is a reflection of this fact. It does not mean that poorer families receive more resources per child.

Figure 13 shows the market and final income Lorenz curves and the concentration curves for education and health spending for each country. Brazil and South Africa "push" the market income Lorenz curve outward (towards the diagonal) the

69 A concentration coefficient is calculated in a way analogous to the Gini coefficient. Let $p$ be the cumulative proportion of the total population when individuals are ordered in increasing income values using market income, and let $C(p)$ be the concentration curve, i.e. the cumulative proportion of total program benefits (of a particular program or aggregate category) received by the poorest $p$ percent of the population. Then, the concentration coefficient of that program or category is defined as $2 \int_{0}^{1}(p-C(p)) d p$.

70 I say "tend" because for global regressivity/progressivity to occur it is not a necessary condition for the share of the benefit to rise/fall at each and every income level. When the latter occurs, the benefit is regressive/progressive everywhere. Whenever a benefit is everywhere regressive/ progressive, it will be globally regressive/progressive, but the converse is not true.

71 This case is also sometimes called progressive in absolute terms.

72 As mentioned above, care must be taken not to infer that any spending that is progressive (regressive) will automatically be equalizing (unequalizing). 


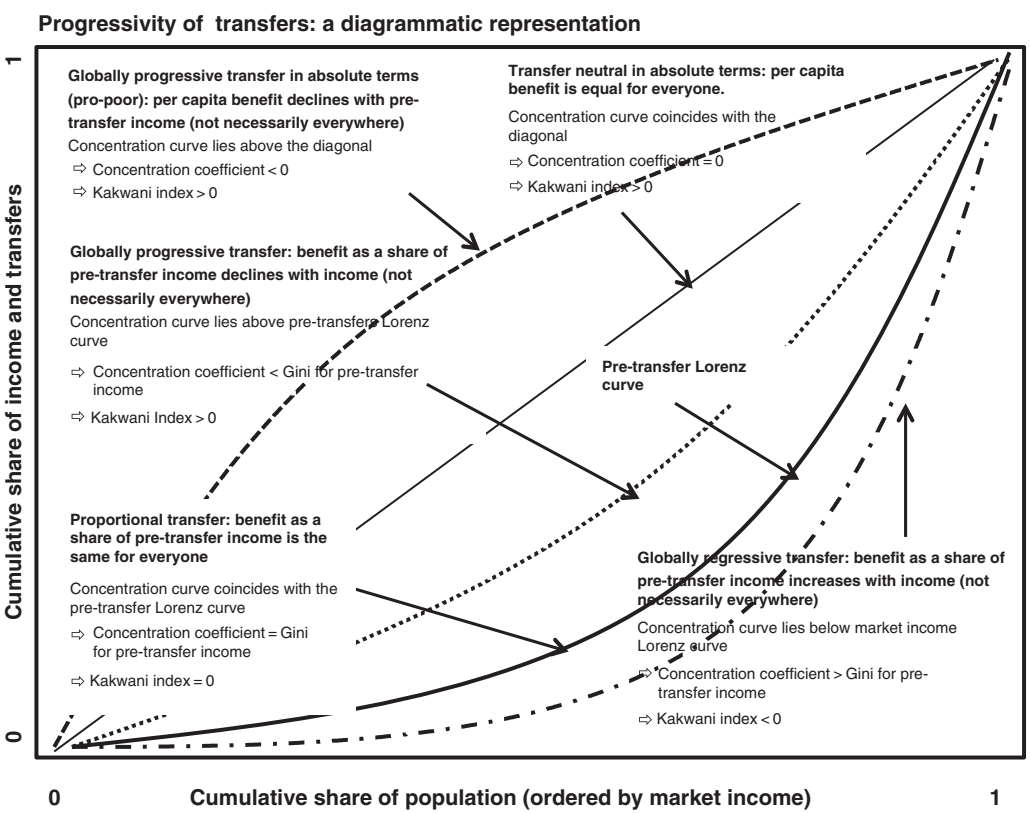

Figure 12: Progressivity of transfers.

Source: Lustig et al. (forthcoming).

most while Indonesia the least. ${ }^{73}$ This result is driven primarily by the level of spending on education and health and its progressivity, as can be observed in Figure 14.

Table 4 summarizes the results regarding the pro-poorness of government spending on education (total and by level) and health. Total spending on education is pro-poor in all countries for which there is data except for Indonesia, where it is (approximately) neutral in absolute terms. Pre-school tends to be pro-poor in all countries for which there is data, particularly so in South Africa. Primary school is pro-poor in all countries. For secondary school, is pro-poor in all countries for which there is data except for Indonesia, where it is (approximately) neutral in absolute terms. Government spending on tertiary education is regressive in Indonesia and progressive only in relative terms in various degrees in the rest. Compared with their respective levels of market income inequality, spending on tertiary education is most progressive in South Africa followed by Colombia and Chile.

Health spending is progressive in only relative terms in Indonesia and Peru; roughly neutral in absolute terms in Mexico; and, pro-poor in Brazil, Chile and

73 The fact that South Africa stands out as the most redistributive is also a consequence of it being the country with the highest market income inequality. See, for example, Figure 7.2 in OECD (2011). 

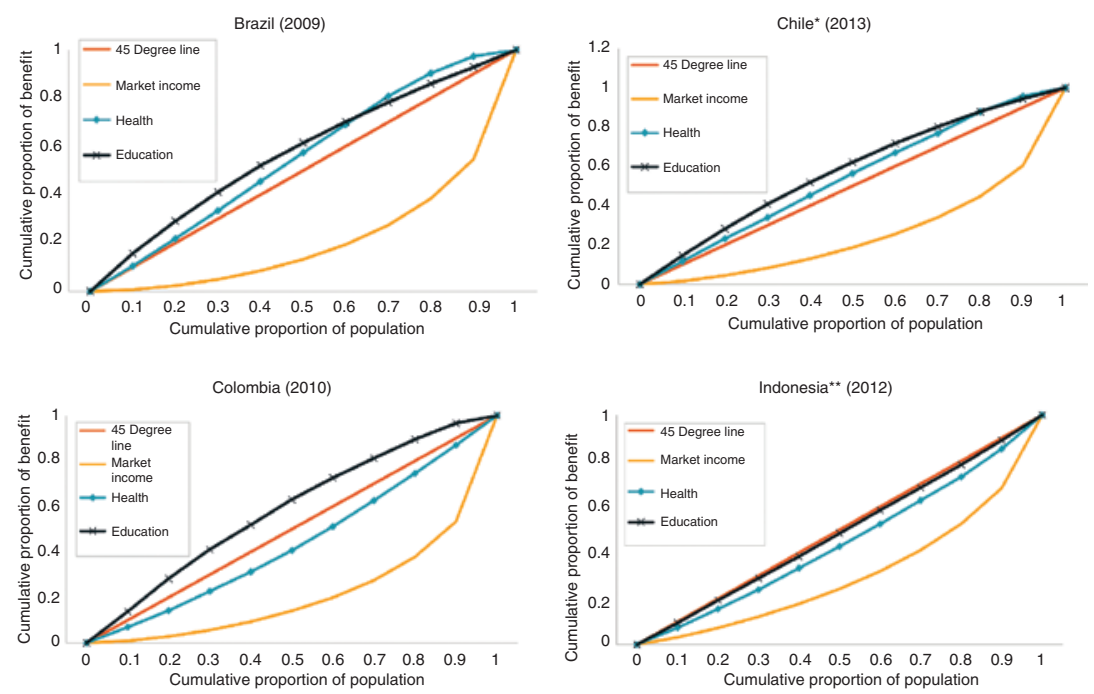

Mexico (2010)
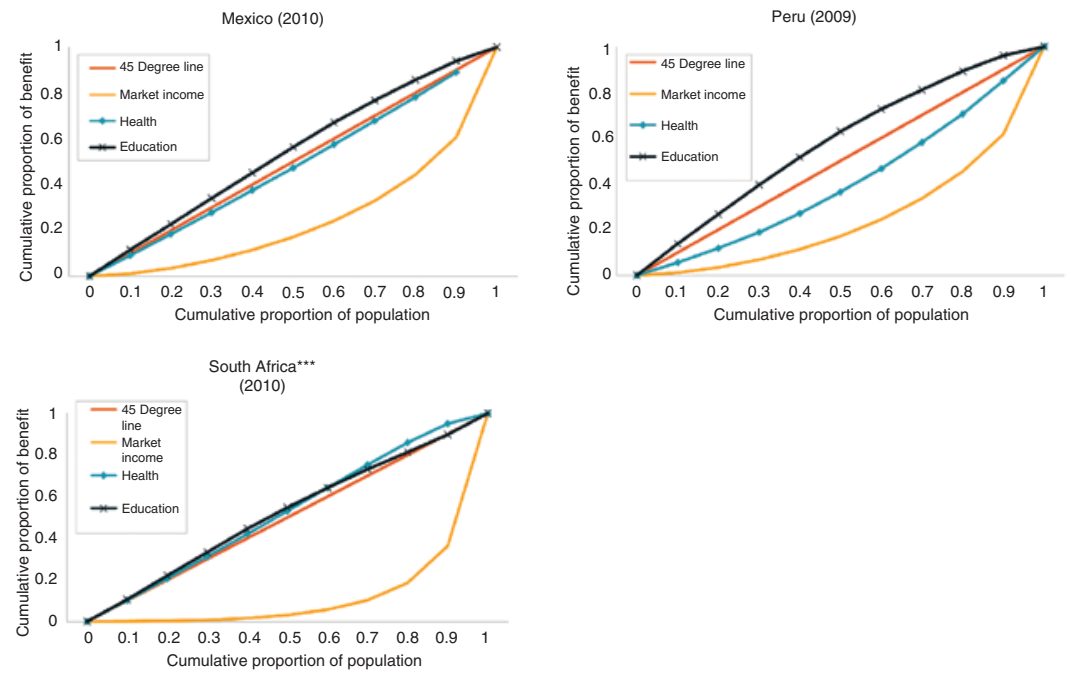

Figure 13: Lorenz curves for market and final income and concentration curves for education and health (Circa 2010).

Source: Author's calculations based on Brazil: Higgins and Pereira (2014); Chile: MartinezAguilar et al. (2016); Colombia: Lustig and Melendez (2015); Indonesia: Afkar et al. (2016); Mexico: Scott (2014); Peru: Jaramillo (2014); South Africa: Inchauste et al. (2015). Note: Year of household survey next to name.

*Chile only has a pay-as-you-go system for older workers and a fully funded system running since 1980 based on individual accounts.

**The Indonesian survey does not include individuals beyond the income at which direct taxes begin to apply; this scenario uses a consumption-based survey.

$\star \star \star T h e ~ s c e n a r i o$ for South Africa assumed free basic services are direct transfers. 

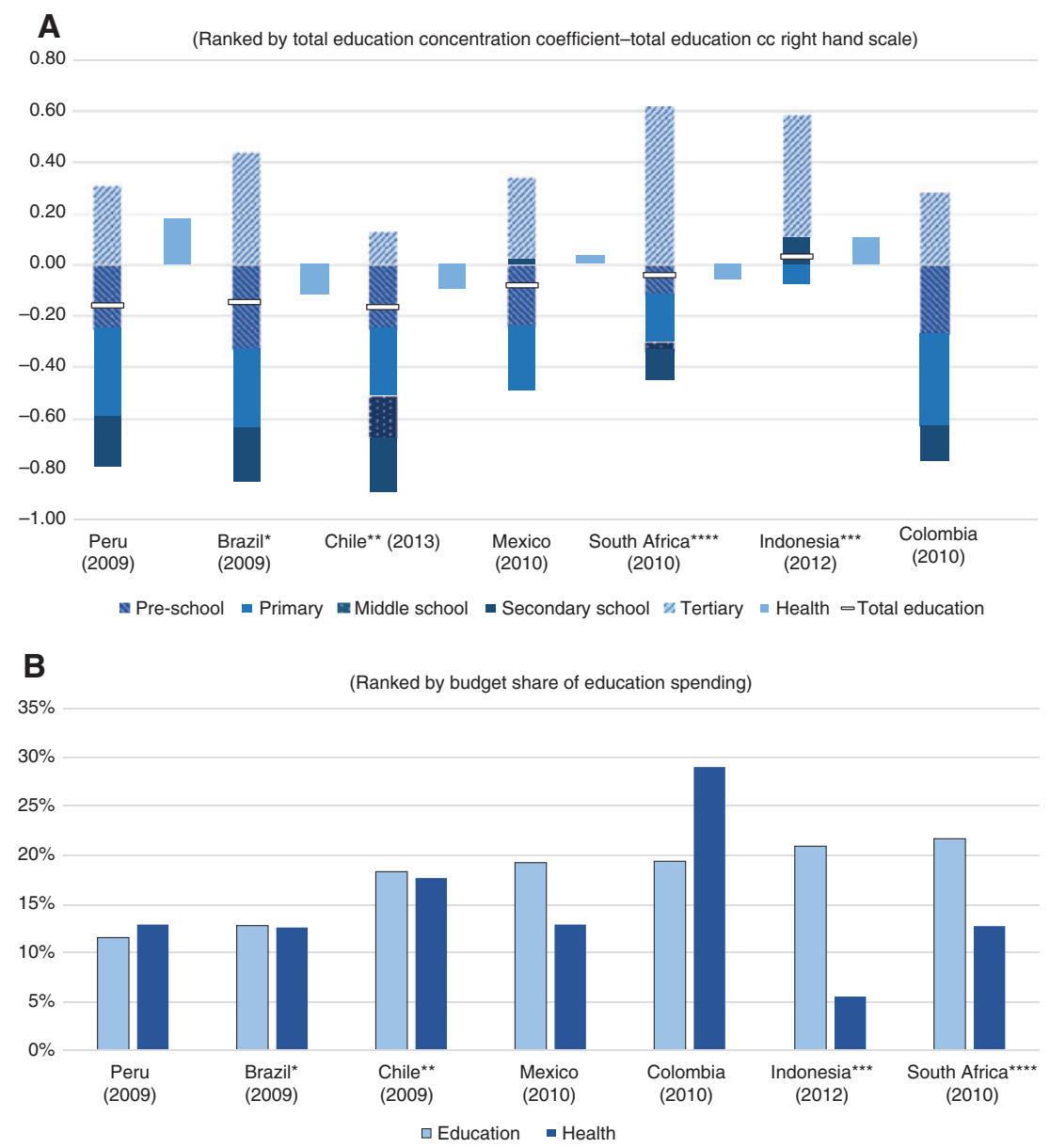

Figure 14: Concentration coefficients and budget shares for education and health.

Panel A. Concentration coefficients for education and health. Panel B. Education and health spending as a share of household market income. Source: Lustig (2015b).

Note: Year of survey in parenthesis. Budget share is measured with total spending on direct transfers, education and health in the denominator.

*Note that the total for education spending on this figure does not equal total education spending in Brazil because the latter includes spending on other types of education, an item that accounts for 1.3 percent of GDP (9.95 Percent of the budget).

**Chile only has a pay-as-you-go system for older workers and a fully funded system running since 1980 based on individual accounts.

***The Indonesian survey does not include individuals beyond the income at which direct taxes begin to apply; this scenario uses a consumption based survey.

$\star \star \star \star$ Note that the total for education spending on this figure does not equal total education spending in South Africa because the latter includes spending on other types of education, an item that accounts for 1.05 percent of GDP (7.27 percent of the budget). 


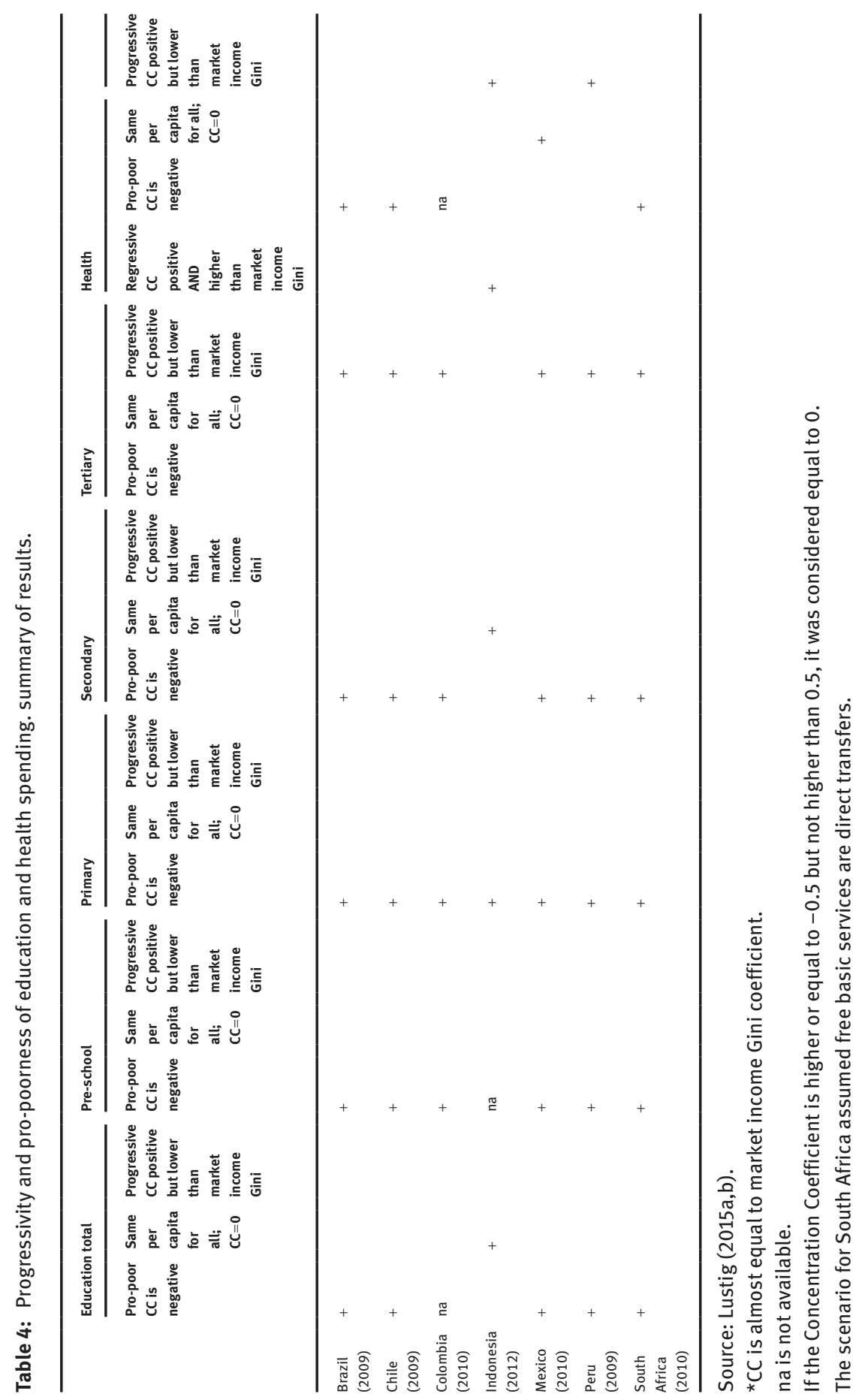


South Africa. Compared to their market income inequality (i.e. the Kakwani index), the lowest progressivity is found in Indonesia and Peru.

While the results regarding the pro-poorness of spending on education and health are quite encouraging, a caveat is in order. Guaranteeing access and facilitating usage of public education and health services for the poor is not enough. As long as the quality of schooling and healthcare provided by the government is low, distortive patterns (e.g. mostly the middle-classes and the rich benefitting from free tertiary education), ${ }^{74}$ such as those observed in Brazil and South Africa, will be a major obstacle to the equalization of opportunities. However, with the existing information, one cannot disentangle to what extent the progressivity or pro-poorness of education and health spending is a result of differences in family composition (i.e. the poor have more children and, therefore, poor households receive higher benefits in the form of basic education transfers) or frequency of illness (i.e. the poor have worst health than the nonpoor) versus the "opting-out" of the middle-classes and the rich.

\section{Conclusions}

In this paper, I examine the redistributive impact of fiscal policy in seven middleincome countries: Brazil, Chile, Colombia, Indonesia, Mexico, Peru and South Africa. In particular, I address the following questions: What is the impact of fiscal policy on inequality and poverty? What is the contribution of direct taxes and transfers, indirect taxes and subsidies, and spending on education and health to the overall reduction in inequality? How pro-poor is spending on education and health?

To put the fiscal redistribution efforts in context, the paper starts by analyzing the levels and trends of income inequality (measured by the Gini coefficient) by region, development level and individual countries and for the world as a whole. With a Gini of 0.38 , in 2010 world inequality can be classified as moderate. During the 2000s, world inequality has fallen a bit and there is some evidence in support of inequality convergence. Latin America and the Caribbean is the most unequal region by far but it is also the one that experienced the largest decline. South Asia came next. In the rest of the regions inequality stayed the same or experienced an increase. During the 2000s, a decline in inequality was more frequent that an increase: of 78 countries, 45 showed a decline. With respect to the seven countries analyzed here, inequality increased in Indonesia and South Africa and declined in the rest.

74 Among the reasons for this outcome is the fact that children of poor households tend to drop out of high school more and the rich children who receive enough quality (often private) education are better equipped to pass the entrance examination. 
In order to analyze the impact of fiscal policy on income inequality it is useful to separate the "cash" portion of the system (direct and indirect taxes, direct transfers and indirect subsidies) from the "in kind" portion (the monetized value of the use of government education and health services). The results show that the reduction in inequality induced by the cash portion of the fiscal system is quite heterogeneous, with South Africa redistributing the most and Indonesia the least. Redistributive success is determined primarily by the amount of resources devoted to (collected from) direct transfers (direct taxes) and their combined progressivity, and the presence of unequalizing net indirect taxes.

While the cash portion of the net fiscal system is always equalizing, the same cannot be said for poverty. In Brazil the headcount ratio measured with the international extreme poverty line of US $\$ 2.50$ ppp per day is higher for consumable income than for market income when pensions are not treated as a transfer. In this country, fiscal policy increases poverty, meaning that a significant number of the market income poor (nonpoor) are made poorer (poor) by taxes and transfers (Higgins and Lustig, op. cit.). This startling result is primarily the consequence of high consumption taxes on basic goods.

The marginal contribution of direct taxes and direct transfers is almost always equalizing. The marginal contribution of direct transfers is higher than the marginal contribution of direct taxes in all the countries. The effect of indirect taxes is unequalizing in Colombia and Indonesia but equalizing in Chile and neutral in South Africa. In Chile, indirect taxes are regressive, and yet equalizing. That is, in this country one finds the counter-intuitive result uncovered by Lambert (2001): a regressive tax is not always unequalizing. Indirect subsidies are equalizing. Measured with respect to market income, the marginal contribution of contributory social security old-age pensions is equalizing in Brazil, Chile and Indonesia and slightly unequalizing in Colombia, Mexico and Peru. Except for Brazil, the order of magnitude of the marginal contribution is rather small.

Turning now to the in-kind portion of the fiscal system, the marginal contribution of spending on education and health is always equalizing and rather large. The latter is not surprising given that the use of government services is monetized at a value equal to average government cost. Total spending on education is propoor in all countries except for Indonesia, where it is (approximately) neutral in absolute terms. Pre-school tends to be pro-poor in all countries for which there is data, particularly so in South Africa. Primary school is pro-poor in all countries. Secondary school, tends to be pro-poor in all countries for which there is data, but it is progressive only in relative terms in Indonesia. Government spending on tertiary education is regressive in Indonesia and progressive only in relative terms in various degrees in the rest. Compared with their respective levels of market income inequality, spending on tertiary education is most progressive in South Africa 
followed by Colombia and Chile. Health spending is progressive in only relative terms in Indonesia and Peru; roughly neutral in absolute terms in Mexico; and, propoor in Brazil, Chile, and South Africa. Compared to their market income inequality (i.e. the Kakwani index), the lowest progressivity is found in Indonesia and Peru.

While the results concerning the distribution of the benefits of in-kind services in education and health are encouraging from the equity point of view, it is important to note that they may be due to factors one would prefer to avoid. The more intensive use of services in education and health on the part of the poorer portions of the population, for example, may be caused by the fact that, in their quest for quality, the middle-classes (and, of course, the rich) chose to use private providers. This situation leaves the poor with access to second-rate services. In addition, if the middle-classes opt out of public services, they may be much more reluctant to pay the taxes needed to improve both the coverage and quality of services than they would be if services were used universally.

There are a few lessons that emerge from the analysis. Let's start with those pertaining to the diagnostic of fiscal redistribution. First, the fact that specific fiscal interventions can have countervailing effects underscores the importance of taking a coordinated view of both taxation and spending rather than pursuing a piecemeal analysis. Efficient regressive taxes (such as the VAT) when combined with generous well-targeted transfers can result in a net fiscal system that is equalizing. Even more, because a net fiscal system with a regressive tax could be more equalizing than without it (Lambert's conundrum), policy recommendations - such as eliminating the regressive tax-based on a piecemeal analysis could be flatly wrong. Second, to assess the impact of the fiscal system on people's standard of living, it is crucial to measure the effect of taxation and spending not only on inequality but also on poverty: the net fiscal system can be equalizing but poverty-increasing.

Regarding policy prescriptions, one fundamental lesson emerges: governments should design their tax and transfers system so that the after taxes and transfers incomes (or consumption) of the poor are not lower than their incomes (or consumption) before fiscal interventions. Leaving out in-kind transfers, the so-called cash portion of the fiscal system should not impoverish the poor (or make poor the nonpoor). The results shown above indicate that both in Brazil and Peru, for example, the moderate poor -on average- are net payers into the fiscal system. In the case of Brazil, the cause is the high consumption taxes paid on staple goods. In the case of Peru, cash transfers are too small to compensate for what the poor pay in taxes. Furthermore, as shown in Higgins and Lustig (op. cit.), fiscal impoverishment can be quite pervasive and, in low income countries, larger in magnitude than fiscal gains to the poor. The current policy discussion (and the literature) focuses primarily on the power of fiscal policy to reduce inequality and much less (and often not at all) on the impact of fiscal policy on the standard of living of the poor. 
If the policy community is seriously committed to eradicating income poverty, governments will need to explore ways to redesign taxation and transfers so that the poor do not end up as net payers. This could become an overriding principle in the design of fiscal systems that could be explicitly added to the frameworks proposed by Atkinson (2015) and Stiglitz (2012) to build more equitable societies.

Acknowledgments: This paper was written as part of the comparative research produced by the Commitment to Equity Institute, Tulane University. The section on fiscal redistribution was included in "Inequality and Fiscal Redistribution in Emerging Economies,” Chapter 7, In it Together: Why Less Inequality Benefits All, OECD Publishing. May 2015. For their very valuable comments on an earlier draft, my thanks go to Michael Forster, Horacio Levy, Monika Queisser and Tim Smeeding as well as to the anonymous reviewer; to Grace Perez-Navarro and Peter Van De Ven for additional helpful comments to this version; and, to Pauline Fron and her colleagues at OECD for their advice on how to make OECD data on social spending comparable with that included here. Also, I am very grateful to Sebastian Molina and Dan Teles for putting together the information on inequality by region and by country, to Luis Felipe Munguia, Sandra Martinez and Yang Wang for their excellent help in preparing the figures and tables as well as to Israel Martinez for updating them in light of new or revised results. All errors and omissions remain my sole responsibility.

\section{References}

Afkar, R., J. Jellema and M. Wai-Poi (2016) “The Distributional Impact of Fiscal Policy in Indonesia.” In: (Inchauste, Gabriela and Nora Lustig, eds.) The Distributional Impact of Fiscal Policy: Experience from Developing Countries. Washington, DC: World Bank, forthcoming.

Atkinson, Anthony B. (2015) Inequality. What Can Be Done? Cambridge, Massachusetts: Harvard University Press.

Bourguignon, F. (2015) The Globalization of Inequality. Princeton: Princeton University Press. Breceda, K., J. Rigolini and J. Saavedra (2008) “Latin America and the Social Contract: Patterns of Social Spending and Taxation.” Policy Research Working Paper 4604. World Bank Latin American and Caribbean Region Poverty Department Poverty Reduction and Economic Management Division. Washington DC: World Bank. Available online http://go.worldbank. org/BWBRP91A50.

Cornia, A. G. ed. (2014) Falling Inequality in Latin America: Policy Changes and Lesssons, WIDER Studies in Development Economics. Oxford, United Kingdom: Oxford University Press, January.

Duclos, J. and A. Araar (2006) Poverty and Equity: Measurement, Policy and Estimation with $D A D$ (Vol. 2). New York, NY: Springer.

Ebrill, L. P., M. Keen and V. P. Summers (2001) The Modern VAT. Washington, DC: International Monetary Fund.

Engel, E. M. R. A., A. Galetovic and C. E. Raddatz (1999) "Taxes and Income Distribution in Chile: Some Unpleasant Redistributive Arithmetic,” Journal of Development Economics, 59:155-192. 
EUROMOD (2015) “Statistics on Distribution and Decomposition of Disposable Income.” Available at: http://www.iser.essex.ac.uk/euromod/statistics/using EUROMOD version no. G2.0.

Ferreira, F. H. G., J. Messina, J. Rigolini, L. F. López-Calva, M. A. Lugo and R. Vakis (2012) Economic Mobility and the Rise of the Latin American Iddle Class. Washington, DC: The World Bank.

Förster, M. and P. Whiteford (2009) "How much Redistribution do Welfare States Achieve? The Role of Cash Transfers and Household Taxes," CESifo DICE Report, Ifo Institute for Economic Research at the University of Munich, 7(3):34-41.

Goñi, E., J. H. López and L. Servén (2011) “Fiscal Redistribution and Income Inequality in Latin America," World Development, 39(9):1558-1569.

Higgins, S. and C. Pereira (2014) “The Effects of Brazil's Taxation and Social Spending on the Distribution of Household Income.” In: (Lustig, Nora, Carola Pessino and John Scott, eds.) The Redistributive Impact of Taxes and Social Spending in Latin America. Special Issue. Public Finance Review, May, Volume 42, Issue 3 and CEQ Master Workbook: Brazil, November 4.

Higgins, S. and N. Lustig (2016) "Can a Poverty-Reducing and Progressive Tax and Transfer System Hurt the Poor?" Journal of Development Economics, 122:63-75.

Higgins, S., N. Lustig, W. Ruble and T. Smeeding (2015) "Comparing the Incidence of Taxes and Social Spending in Brazil and the United States." Review of Income and Wealth. DOI: 10.1111/roiw.12201.

Immervoll, H. and C. O’Donoghue (2001) “Imputation of Gross Amounts from Net Incomes in Household Surveys: An Application using EUROMOD”, EUROMOD Working Paper EM1/01, University of Essex, Available at: https://www.iser.essex.ac.uk/research/publications/ working-papers/euromod/em1-01.pdf.

Immervoll, H. and L. Richardson (2011) "Redistribution Policy and Inequality Reduction in OECD Countries: What Has Changed in Two Decades?” IZA Discussion Paper No. 6030.

Immervoll, H., L. Horacio, J. R. Nogueira, C. O’Donoghue and R. Bezerra de Siqueira (2009) “The Impact of Brazil's Tax-Benefit System on Inequality and Poverty." In: (Stephan Klasen and Felicitas Nowak-Lehmann, eds.) Poverty, Inequality, and Policy in Latin America. Cambridge: Mass.: MIT Press, pp. 271-302.

Inchauste, G., N. Lustig, M. Maboshe, C. Purfield and I. Wollard (2015) "The Distributional Impact of Fiscal Policy in South Africa." In: (Inchauste, G., Lustig, N. eds.) The Distributional Impact of Fiscal Policy: Experience from Developing Countries. Washington, DC: World Bank.

Jaramillo, M. (2014) “The Incidence of Social Spending and Taxes in Peru." In: (Lustig, Nora, Carola Pessino and John Scott, eds.) The Redistributive Impact of Taxes and Social Spending in Latin America. Special Issue. Public Finance Review, May, Volume 42, Issue 3 and CEQ Master Workbook: Peru, June 21, 2013.

Kakwani, N. C. (1977). “Measurement of Tax Progressivity: An International Comparison.” The Economic Journal, 87(345):71-80.

Keen, M. and B. Lockwood (2010) “The Value Added Tax: Its Causes and Consequences." Journal of Development Economics, 92:138-151.

Lambert, P. (2001). The Distribution and Redistribution of Income. 3rd ed. Manchester, UK: Manchester University Press.

Leibbrandt, M., I. Woolard, A. Finn and J. Argent (2010) "Trends in South African Income Distribution and Poverty since the Fall of Apartheid." OECD Social, Employment and Migration Working Papers, No. 101, OECD Publishing, OECD. doi:10.1787/5kmms0t7p1ms-en.

Lindert, K., E. Skoufias and J. Shapiro (2006) "Redistributing Income to the Poor and Rich: Public Transfers in Latin America and the Caribbean." Social Protection Discussion Paper 0605. Washington, DC: The World Bank. 
López-Calva, L. F. and N. Lustig (2010) Declining Inequality in Latin America: A Decade of Progress? Washington, DC and United Nations Development Programme (UNDP), New York: Brookings Institution Press.

López-Calva, L. F. and E. Ortiz-Juárez (2014) "A Vulnerability Approach to the Definition of the Middle Class." Journal of Economic Inequality, 12(1):23-47.

Lustig, N. (2015a) Fiscal Policy, Inequality and the Poor in the Developing World. CEQ Working Paper No. 23, Center for Inter-American Policy and Research and Department of Economics, Tulane University and Inter-American Dialogue, forthcoming.

Lustig, N. (2015b) "The Redistributive Impact of Government Spending on Education and Health: Evidence from 13 Developing Countries in the Commitment to Equity Project." In: (B. Clements, R. de Mooij, S. Gupta and M. Keen, eds.) Chapter 16 Inequality and Fiscal Policy, International Monetary Fund: Washington.

Lustig, N. and S. Higgins (2013). "Commitment to Equity Assessment (CEQ): Estimating the Incidence of Social Spending, Subsidies and Taxes. Handbook.” CEQ Working Paper No. 1, July 2011; revised January 2013. New Orleans, LA.

Lustig, N and M. Melendez (2015) "The Impact of Taxes and Transfers on Inequality and Poverty in Colombia." CEQ Working Paper No 24, Center for Inter-American Policy and Research and Department of Economics, Tulane University and Inter-American Dialogue. forthcoming.

Lustig, N., C. Pessino and J. Scott. eds. (2014). The Redistributive Impact of Taxes and Social Spending in Latin America. Special Issue. Public Finance Review, May, Volume 42, Issue 3.

Lustig, N., A. Enami and R. Aranda (forthcoming) "The Analytics of Fiscal Redistribution." Chapter In: (Lustig, Nora and Sean Higgins, eds.) Commitment to Equity Handbook: Estimating the Redistributive Impact and Pro-poorness of Fiscal Policy.

Martinez-Aguilar, S., A. Fuchs and E. Ortiz-Juarez (2016) "The Impact of Fiscal Policy on Inequality and Poverty in Chile." CEQ Working Paper No. 46, Commitment to Equity Institute, Tulane University and the World Bank, forthcoming.

Martínez-Vazquez, J. (2008) "The Impact of Budgets on the Poor: Tax and Expenditure Benefit Incidence Analysis." In: (B. Moreno-Dodson and W. Quentin, eds.) Public Finance for Poverty Reduction: Concepts and Case Studies from Africa and Latin America. Washington, DC: World Bank.

Musgrave, R. (1959) The Theory of Public Finance. New York: McGraw-Hill.

OECD (2011) Divided We Stand. Why Inequality Keeps Rising. OECD Publishing. Available at: http://dx.doi.org/10.1787/9789264119536-en.

O’Higgins, M. and P. Ruggles (1981) “The Distribution of Public Expenditures and Taxes Among Households in the United Kingdom," Review of Income and Wealth, 27(3):298-326.

Pechman, J. A. (1985) Who Paid the Taxes, 1966-1985. Washingon, DC: Brookings Institution. Ravallion, M. (2003) “Inequality Convergence," Economics Letters, Elsevier, 80(3):351-356.

Ruggles, P. and M. O'Higgins (1981) "The Distribution of Public Expenditure Among Households in the United States," Review of Income and Wealth, 27:137-163.

Sahn, D. and S. Younger (2000) "Expenditure Incidence in Africa: Microeconomic Evidence," Fiscal Studies, 21(3):329-347.

Scott, J. (2014) “Redistributive Impact and Efficiency of Mexico’s Fiscal System.” In: (Lustig, Nora, Carola Pessino and John Scott, eds.) The Redistributive Impact of Taxes and Social Spending in Latin America. Special Issue. Public Finance Review, May, Volume 42, Issue 3, 368-390.

Shorrocks, A. F. (2013) "Decompositon Procedures for Distributonal Analysis: A Unified Framework Based on the Shapley Value," Journal of Economic Inequality, 11(1):99-126. Stiglitz, Joseph E. (2012) The Price of Inequality. New York: W. W. Norton and Company. 